\title{
How Have M\&As Changed? Evidence from the Sixth Merger Wave
}

\author{
G.Alexandridis, C.F. Mavrovitis, and N.G. Travlos*
}

June 2011

\begin{abstract}
We examine the characteristics of the sixth merger wave that started in 2003 and came to an end approximately in late-2007. The drivers of this wave lie primarily in the availability of abundant liquidity, in line with neoclassical explanations of merger waves. Acquirers were less overvalued relative to targets and merger proposals comprised higher cash elements. Moreover, the market for corporate control was less competitive, acquirers were less acquisitive, managers displayed less over-optimism and offers involved significantly lower premiums, indicating more cautious and rational acquisition decisions. Strikingly however, deals destroyed at least as much value for acquiring shareholders as in the 1990s.
\end{abstract}

Keywords: Merger waves, public acquisitions, premium, shareholder gains, method of payment.

JEL Classification: G14, G30, G34

*Alexandridis and Mavrovitis are from the ICMA Centre, Henley Business School, Reading University, U.K. Travlos is from ALBA Graduate Business School, Greece. Corresponding author's email address: ntravlos@alba.edu.gr. Travlos acknowledges financial support received from the Kitty Kyriacopoulos Chair in Finance. All errors are our own. 


\section{How have M\&As Changed? Evidence from the Sixth Merger Wave}

\section{Introduction}

Recent studies have examined the characteristics and success of M\&As during the fifth merger cycle that started in 1993 and peaked in 2000 where over $\$ 1.4$ trillion was spent on U.S. deals. This was marked by extensive overpayment, mega-deals, overvaluation of acquiring firms, prevalence of equity financing, and significant value destruction for acquiring firm shareholders (Andrade, Mitchell, and Stafford, 2001; Dong, Hirshleifer, Richardson, and Teoh, 2006; and Moeller, Schlingemann, and Stulz, 2005). The sixth merger wave emerged in 2003, only about three years after technology bubble burst and the end of the fifth merger cycle. M\&A activity peaked in 2006 with more than $\$ 1$ trillion spent on deals within the U.S. The new wave came to an end approximately in late-2007, when investors and corporate managers started showing real signs of skepticism about the state of the MBS and credit markets and their potential ripple effects on the financial system and the economy as a whole. As the crisis unfolded, credit tightened and financing became scarce, bringing deals to a halt. The general macro-, micro-economic, corporate governance and capital market environment significantly evolved during and following the recession stage that ensued the fifth merger cycle. Moreover, important lessons were learned from the fifth merger wave that may have resulted in improvements in the quality of acquisition decisions. In this paper we examine whether the characteristics and success of deals that took place during the sixth merger wave diverge from the previous experience.

It appears that behavioral theories according to which merger waves are more likely to occur as a result of overvalued firms seeking to acquire less overvalued assets (Shleifer and Vishny, 2003 and Rhodes-Kropf and Viswanathan, 2004) are unlikely to explain the sixth merger cycle. It is conventionally believed that the thriving stock prices amid this wave 
were based more on sound fundamentals, rather than over-optimistic expectations. The mean monthly inflation adjusted P/E ratio for S\&P500 was about 39 during 1998-1999 while less than 26 between 2005 and 2006. ${ }^{1}$ Accordingly, we find that during the sixth merger wave acquirers' assets were less highly valued and the valuation diversity between acquirers and targets was narrower relative to the 1990s wave. ${ }^{2}$ Moreover, the post millenium era is characterized by lower U.S. corporate loan prime rates and stronger cash balances for acquirers, resulting in more debt and free cash financing of merger deals respectively. It is therefore more likely that the sixth merger wave was mainly propagated by the availability of abundant liquidity, in the spirit of Harford's (2005) neoclassical explanation. Both, access to cash (Martin, 1996) and firm valuations (Shleifer and Vishny, 2003) have been associated with the choice of the method of payment and can explain why a much smaller fraction of deals was financed with stock as opposed to the 1990s paradigm. The proportion of stockswap financed acquisitions dropped by more than $57 \%$ while the overall amount of equity in the financing decreased by about $32 \%$. In contrast, both the purely cash financed transactions as well as the cash element in acquisition offers increased to levels last observed in the $1980 s^{3}$

Further, it is possible that the bullish managerial and investor sentiment during the fifth merger wave led to record levels of merger activity and regular "control contests" that made acquirers bid more aggressively and, as a result, be prone to overpayment. If managers have learned from this experience, then hubris or empire building motivated acquisition decisions should be less frequent during the sixth merger cycle and competition for listed

\footnotetext{
${ }^{1}$ Data are from Bob Shiller's Web site (www.irrationalexuberance.com/index.htm).

${ }^{2}$ Rhodes-Kropf, Robinson, and Viswanathan (2005) and Dong et al. (2006) find that acquirers were more overvalued than targets in the 1980s and 1990s.

${ }^{3}$ Shleifer and Vishny (1991) report that acquisitions during the $4^{\text {th }}$ merger wave were more frequently financed with cash . Andrade, Mitchel and Staford (2001) find that the fraction of cash financed deals during the 1980s was about $45 \%$. Availability of liquidity is cited among the drivers of the $4^{\text {th }}$ merger cycle that also include relaxation of regulatory restrictions that led to an increase in hostile deals and bust-up takeovers as well as a plethora of LBOs.
} 
targets should be less intense. We show that the market for corporate control was by $55.1 \%$ (16.4\%) less competitive in 2003-2007 compared to 1993-1999 based on the value (number) of listed firms being targeted in successful deals. Acquisitions by frequent acquirers, that have been associated with managerial hubris (Billett and Qian, 2008), were also by $35 \%$ less common during the sixth merger wave. A CEO overconfidence measure based on the timing of option exercise following Malmendier and Tate (2008) also reflects lower levels of managerial overconfidence. Given that premiums increase with takeover competition (Fishman, 1988; and Alexandridis, Petmezas, and Travlos, 2010) and managerial overoptimism (Roll, 1986), we should expect that acquirers offered less generous premiums during the sixth merger wave. Moreover, Starks and Wei (2004) and Wang and Xie (2009) show that the quality of corporate governance of the acquirer is negatively associated with the offer premium. Therefore, premiums may have also decreased due to the corporate governance improvements brought forward by the Sarbanes-Oxley Act in the second half of 2002. Along these lines, we find that the average premium paid in public acquisitions during the sixth merger cycle was $37.9 \%$ compared to $45.0 \%$ during the $1993-1999$ period. $^{4}$ This divergence in premiums is statistically significant and robust to different premium measures used, while it is not driven by any particular industries or other deal and firm characteristics.

These findings lead to another main conjecture; that, all else equal, acquirers should have been able to retain more of the potential benefit from deals and create more value for their shareholders. In an efficient market, we would therefore expect that investors perceive public acquisition announcements more favorably than in the past. ${ }^{5}$ Our evidence suggests that this is in fact not the case. Acquirers continued to realize significant losses around acquisition announcements, similar or worse in magnitude to the previous experience. More

\footnotetext{
${ }^{4}$ Officer (2003) reports that acquirers paid on average premiums of 55\% in public acquisitions between 1988 and 2000.

${ }^{5}$ Along these lines, McKinsey \& Co reports that during the latest M\&A cycle (up to 2006) acquirers have been more disciplined about creating value for their shareholders (Dobbs et al., 2007).
} 
specifically, cash financed deals that took place in 2003-2007 did not create value for acquiring firms shareholders, in contrast to the 1990s, while stock-swap transactions continued to result in extensive losses. The fact that cash financed acquisitions destroyed more value during the sixth merger wave may be explained by the fact that cash paying acquirers had much stronger cash reserves and excess cash balances can exacerbate the free cash flow problem (Jensen, 1986) and lead to value destroying acquisition decisions (Harford, 1999). Results based on long-run stock performance corroborate that acquirers did not create more shareholder value during the sixth merger wave. Target firms experienced similar or in some cases worse abnormal returns, which can be attributed to the inferior premiums offered. Consequently, acquisitions during the sixth merger wave were not associated with superior combined gains.

Our work offers important contributions. First, we present new evidence on the sixth merger wave. We show this is not driven by overvaluation motives since acquiring firms i) are less, if at all, overvalued, ii) buy targets subject to similar valuations to their own, iii) finance their acquisitions with stock-swaps infrequently. Instead, it appears that liquidity, a fundamental element of more neoclassical theories, can help propagate merger waves. Of course this does not invalidate "behavioral" theories but rather corroborates that it does not take misvalued markets or firms for merger activity to thrive. Second, we show that control premia have decreased through time and are significantly lower during the sixth merger wave. On the one hand, this can imply more cautious and rational acquisition decisions and possibly an improved acquisition process as a whole where acquirers seek to retain more of the synergy gains for their shareholders. However, the finding that acquirers continued to destroy value for their shareholders, and in some cases in fact destroyed more value than in the past, attests that the payment of lower premiums is not sufficient to warrant value creation. A potential explanation for the lower returns in the sixth merger cycle is based on 
investor sentiment. Rosen (2006) finds evidence that short-run abnormal returns to acquirers are higher during periods preceded by more investor over-optimism. Accordingly, Bouwman et al. (2009) report a positive relation between market valuations and short-run acquirer gains. Our tests show that i) market returns prior to deals in the $5^{\text {th }}$ merger wave are significantly higher than preceding deals that took place during the $6^{\text {th }}$ wave and ii) while both merger waves are classified as "high valuation" periods, still, inflation adjusted market $\mathrm{P} / \mathrm{E}$ ratios are significantly higher during the fifth merger wave. Both these findings suggest that investor sentiment thrived during the fifth merger wave which may explain why returns to acquirers were on average less negative.

The rest of the paper is organized as follows. Section II describes the data and methodology used in our investigation and discusses the sample statistics. Section III evaluates and compares acquisition premiums and shareholder gains of the two most recent merger waves. Finally section IV provides concluding remarks.

\section{Data, Statistics, and Methodology}

The sample of acquisition announcements is from SDC and includes U.S., domestic, completed deals that took place between 1993 and 2007. For the initial analysis related to the identification of the merger waves both the acquirer and target firm can be either public, private or subsidiary, as classified by SDC. Figure 1 shows the dollar value spent in all deals through time. The fifth merger wave started developing in 1993 where the total deal value surged by more than $70 \%$ from the one year earlier and then continued building-up until 1998. ${ }^{6}$ The market for corporate control remained highly active in 1999 and 2000 where more than $\$ 1.3$ and $\$ 1.4$ trillion respectively was spent on M\&As. The total transaction value plummeted by 55\% in 2001 and a further 39\% in 2002. The sixth merger wave started in

\footnotetext{
${ }^{6}$ The unreported total deal value for 1992 was $\$ 160$ billion.
} 
2003 , with an increase in the total value spent of almost $30 \%$, and peaked in 2006 , where the value reached \$1.13 trillion, before significantly dropping in late 2007.

[Please Insert Figure 1 About Here]

Goel and Thakor (2010) use a de-trended market P/E ratio measure as in Bouwman et al. (2009) to identify merger waves. ${ }^{7}$ Based on this measure the great majority of months between 1993-1999 and 2003-2007 are classified as merger wave months. In contrast, all months within the 2000-2002 period are not classified as merger wave months. We also follow Harford's (2005) methodology to identify 24-month merger wave peaks. We first classify potential merger wave periods at the aggregate level by taking the highest 24-month merger bid concentration in each of the periods 1993-2000 and 2001-2007. We then perform 1000 simulations that randomly assign each merger bid to a month within the corresponding period. If concentration in the actual 24-month period is higher than $95 \%$ of the simulation based 24-month highest concentrations, then this period is classified as a merger wave peak. This method suggests that two merger wave peaks occurred in 1998-1999 and 2005-2006. Performing the analysis at the industry level, based on a modified Fama and French 6-sector classification, verifies that there was a wave peak for all six industries around the same periods. ${ }^{8}$

As most of our analysis focuses on relative valuations, acquisition gains and premiums we concentrate on public acquisitions that comprise the majority of the total value

\footnotetext{
${ }^{7} \mathrm{~A}$ month is classified as merger-wave month if its de-trended market $\mathrm{P} / \mathrm{E}$ was above the average market $\mathrm{P} / \mathrm{E}$ over the past five-years.

${ }^{8}$ We modify the 5-industry classification from Kenneth French's website (Consumer, Manufacturing, HiTec, Healthcare, Other) by adding an additional category of "Financials" (SIC codes 6000-6999) which was originally included within "Other".
} 
spent on all M\&As. ${ }^{9}$ We select transactions where the acquirer owns less than $10 \%$ of the target's shares prior to the acquisition proposal and more than $50 \%$ after the completion of the deal, the transaction value is at least $\$ 1$ million and the size of the target is at least $1 \%$ of the size of the acquirer. Acquiring firms are listed on NYSE, AMEX or NASDAQ and have data on CRSP and COMPUSTAT. Clustered acquisitions, where the acquirer is involved in more than one acquisition proposals within a three day window are omitted from the analysis. ${ }^{10}$ Our final sample consists of 3,206 transactions.

Table 1 reports the sample statistics. Deals are partitioned according to the following periods; 1993-1999 (fifth merger wave), 1998-1999 (fifth wave peak), 2000-2002 (recession), 2003-2007 (sixth merger wave) and 2005-2006 (sixth wave peak). Market capitalization is measured one month prior to the acquisition announcement and is reported in 2007 dollars. Acquirers and targets are generally larger in the sixth merger wave compared to the 1990s but there are no significant variations in the target-to-acquirer relative size across the different periods. Firm overvaluation is measured by Tobin's Q (Jensen, 2005; Moeller et al., 2005) which is the market value of assets over the book value of assets. ${ }^{11}$ Based on this measure, acquirers are markedly more overvalued during the fifth merger wave relative to the sixth. More importantly, it appears that acquirers are in general more highly valued than targets during the fifth merger wave but this is not the case in 2003-2007. As a result, the acquirerto-target relative overvaluation variable (RELQ) is significantly lower during the sixth merger wave. ${ }^{12}$ The evidence here suggests it is unlikely that the sixth merger wave was

\footnotetext{
${ }^{9}$ However, where appropriate, we also examine in unreported tests whether our results are similar for deals by private acquirers or where the target is unlisted and find consistent patterns in most of the cases.

${ }^{10}$ Including clustered acquisitions however does not materially affect our results.

${ }^{11}$ Market value of assets is the book value of total assets minus the book value of common equity plus the market value of common equity. Alternatively, Tobin's Q can proxy for growth opportunities (Lang, Stulz, and Walkling, 1989; Malmendier and Tate, 2008) and management effectiveness (Servaes, 1991; Lang, Stulz, and Walkling, 1989). Nonetheless, results are similar when we use the market-to-book ratio instead of the Tobin's Q.

${ }^{12}$ This could potentially imply less scope for value creation through M\&As during the sixth merger wave.
} 
initiated as a result of overvalued firms seeking to acquire less overvalued assets (Shleifer and Vishny, 2003).

\section{[Please Insert Table 1 About Here]}

Along these lines, Shleifer and Vishny argue that acquisitions driven by overvaluation are more likely paid for with stock-swaps. Both the stock financed transactions and the percentage of equity financing dropped dramatically during the sixth merger cycle. From a $58.06 \%$ high during the fifth merger wave, stock financed transactions in 2003-2007 account for only $24.65 \%$; a drop in stock financing of approximately $58 \%$. The portion of equity in deals also decreased by nearly $32 \%$. Conversely, both cash financed deals and the element of cash in acquisition offers doubled during the sixth merger wave. This financing pattern may have also been the result of lower interest rates and the record high corporate cash balances during this period, leading to more debt and free cash flow financing respectively. The yearly average of the Wall Street Journal's prime rate for the 2003-2007 (2005-2006) period is $6.14 \%(7.07 \%)$ compared to $7.84 \%(8.18 \%)$ for $1993-1999$ (1998-1999). As a result, in the sixth merger wave acquirers have higher industry adjusted debt-to-assets ratios at the fiscal year end following the acquisition announcement year. Moreover, acquirers' assets-adjusted cash balances are also higher than in the 1990s, implying more ample idiosyncratic liquidity. ${ }^{13}$

Although the 2003-2007 period is characterized by heightened merger activity, the market for corporate control for listed companies was less competitive than previously. Competition is measured by the ratio of the number of listed firms acquired to the number of

\footnotetext{
${ }^{13}$ Using sales-adjusted cash reserves produces similar results.
} 
all CRSP firms each year. ${ }^{14}$ We also use the value of all listed firms acquired as a percentage of the market value of all CRSP firms. The fraction of U.S. listed firms targeted in completed deals decreased by over $16 \%$ during the most recent merger wave compared to the 1993 1999. The share of the value of all listed firms acquired in M\&A deals dropped from $3.96 \%$ $(5.56 \%)$ in $1993-1999$ (1998-1999) to $1.78 \%(2.31 \%)$ in 2003-2007 (2005-2006). Acquirers were also less acquisitive during the sixth merger wave and acquisitiveness has been associated with managerial hubris (Malmendier and Tate, 2008 and Billett and Qian, 2008). More than $38 \%$ of all acquisitions in the sample are made by acquirers involved in two or more deals within a two year period. ${ }^{15}$ This share is $42.78 \%$ for $1993-1999$ but only $28.12 \%$ for 2003-2007 which may suggest that acquisition decisions during the sixth merger wave were to a lesser extent driven by managerial over-optimism. We further examine variations in the likelihood of managerial hubris driven acquisition decisions between the two waves by using a measure based on in-the-money unexercised exercisable options held by the acquirer's CEO following Malmendier and Tate (2008). We estimate Holder67 which captures the timing of CEO options exercises. A CEO is classified as overconfident if he fails to exercise her stock options although they are $67 \%$ in-the-money. ${ }^{16}$ Our results again indicate that hubris infected acquirers were less frequent during the sixth merger wave and therefore acquisition decisions are less likely to be motivated my managerial over-optimism. We also capture investor sentiment by using the pre-announcement 6-month buy-and-hold return of the S\&P 500. This 'momentum' indicator is used in Rosen (2006). Market momentum is significantly less pronounced for transactions that took place during the sixth merger wave.

\footnotetext{
${ }^{14}$ A similar measure is used by Alexandridis et al. (2010) to proxy for competition at the country level. A more extensive sample is used for the construction of the competition measure that is based on the number of all listed firms acquired irrespective of the acquiring firm's public status. Using a measure based only on public acquisitions produces similar results.

${ }_{15}$ Our results are similar when using a five year window as in Billett and Qian (2008) or other alternative specifications.

${ }^{16}$ Executive options data is manually collected from DEF 14A proxy statements in SEC filings.
} 
We use two measures of acquisition premium. The first is the offer price over the target's share price four weeks prior to the acquisition announcement and is reported for observations between zero and two as in Officer (2003). ${ }^{17}$ The second is the market adjusted target return for a 190 day window starting 63 days preceding the acquisition announcement, as in Schwert (2000). ${ }^{18}$ Figure 2 depicts acquisition premiums and indicates that they have decreased through time and were unusually low during the sixth merger cycle. Table 1 shows that acquiring firms paid on average a premium of almost $45 \%$ during the fifth merger wave and 48\% during the 1998-1999 peak but less than 38\% during 2003-2007 and 2005-2006. Accordingly, the premium paid for listed targets during the sixth merger cycle (2005-2006) was on average $15.8 \%$ (25.2\%), substantially lower than during 1993-1999 (1998-1999). Premium differentials between the two waves and their peaks are statistically significant at the $1 \%$ level for both mean and median estimates and irrespective of the measure used. ${ }^{19}$

[Please Insert Figure 2 About Here]

For the return analysis we compute abnormal returns of acquiring and target firms using market model returns where parameters are estimated over the period $(-250,-15)$ relative to the announcement day. ${ }^{20}$ The benchmark index used is the CRSP value-weighted index. ${ }^{21}$ Abnormal returns are then cumulated over the three- or 21-day period surrounding the acquisition announcement and are winsorized at the $1 \%$ and $99 \%$ levels. Total acquisition gains are calculated using the market value-weighted average of the acquirer and target

\footnotetext{
${ }^{17}$ For robustness we also use the ratio of the offer price to the 30 -day $(-45,-15)$ volume-weighted average of the target's trading price as a premium measure and our results remain very similar.

${ }^{18}$ Although for brevity we do not report results based on this measure in all tables, they are always very similar to using the first measure.

${ }^{19}$ Acquisition premium differentials are also statistically significant for all payment methods.

${ }^{20}$ Alternatively, using a market-adjusted model where $\alpha=0$ and $\beta=1$ does not materially affect our results.

21 The minimum estimation window is set to 30 days. Equally weighted benchmark returns or alternative estimation windows produce very similar results.
} 
abnormal returns, where market values are measured one month prior to the acquisition announcement.

For the long-run analysis we calculate acquirer performance using average calendartime abnormal returns (ACTARs) to control for the cross sectional dependence of stock returns. Acquirers enter the portfolio at the announcement month and remain for 36 months. Abnormal returns are calculated as follows:

$$
\mathrm{CTAR}_{\mathrm{i}, \mathrm{t}}=\mathrm{R}_{\mathrm{i}, \mathrm{t}}-\mathrm{R}_{\text {Size/BM benchmark }, \mathrm{t}}
$$

where $R_{i, t}$ is the return of acquirer $i$ at month $t$ and $R_{\text {Size/BM benchmark,t }}$ is the return of the corresponding 25 size and book-to-market equity (BE/ME) reference portfolio for the same month as in Mitchell and Stafford (2000). The ACTAR is then given by the universal average of all mean monthly abnormal return observations.

We also estimate monthly abnormal returns for a period of 3 -years following the acquisition announcement using calendar time portfolio regressions (CTPRs) of the following form:

$$
R_{p t}-R_{f t}=\alpha_{p}+b_{p}\left(R_{m t}-R_{f t}\right)+s_{p} S M B_{t}+h_{p} H M L_{t}+u_{p} U M D_{t}+\varepsilon_{p t},
$$

where $R_{p t}-R_{f t}$ is the equally-weighted, monthly calendar time portfolio excess return and the independent variables are the Fama and French (1993) and Carhart (1997) factors. Calendar months with less than 10 return observations are excluded from regressions.

\subsection{Acquisition Premiums by Industry Sector}

If premiums vary by industry and the two waves we examine are characterized by consolidation in different industries, then results may be driven by some particular sectors. If more "irrational" premiums were paid for instance for high-growth companies during the fifth merger wave, then the premium effect we document may be more pronounced for HighTech firms or may be even driven entirely by this sector. 
Table 2 reports acquisition premiums by time period and target industry. We use the Fama and French five industry classification to partition targets into sector groups but report results for financials separately. ${ }^{22}$ No great variation is observed in terms of what type of firms were acquired during the two waves. Acquisitions involving targets in the manufacturing and consumer sectors represent a smaller segment of the sixth merger wave compared to the 1993-1999 period. In contrast, there was an increase in acquisitions of firms within 'Healthcare' and 'Financials'. The highest premiums over the sample period are paid for Hi-Tech targets (52.27\%), followed by 'Other' and 'Consumer' sectors where the mean premium is $49.77 \%$ and $49.10 \%$ respectively. On the other hand, the lowest premiums are paid for financial firms (38.17\%). In general, premiums are lower in 2003-2007 compared to 1993-1999 irrespective of the target sector. Differentials between the most recent merger wave and the fifth merger wave are negative and statistically significant at conventional levels for most sectors. The divergence in premiums is more pronounced in the 'Manufacturing' and 'HiTec' sectors and less intense in the 'Consumer' and 'Other' sectors, where however the number of observations is relatively small. Overall, it appears that the premium differences we document is not driven by any particular industry but is rather a ubiquitous phenomenon. ${ }^{23}$

\footnotetext{
${ }^{22}$ Fama and French group financials (SIC codes 6000-6999) in the "Other" sector subset that also includes firms in the mining, construction, construction material, transportation, hotel, business service, and entertainment sectors. We also partition targets based on 12 and 17 industries according to Fama and French but do not report the results as the number of observations is particularly low for several period-sector sub-sets and this impacts statistical significance. It appears however that premiums during the sixth merger wave are still lower for 11 out of 12 cases and 14 out of 17 cases respectively. In addition, premium differentials between the two merger wave periods remain similar both in terms of direction and significance when we exclude Hi-Tech firms.
} 


\subsection{Acquisition Abnormal Returns}

The fact that acquirers pay lower premiums during the sixth merger wave implies that, all else equal, they should have been able to retain more of the potential benefit from deals and create more value for their shareholders. ${ }^{24}$ We would therefore expect that investors react more favorably to public acquisition announcements. On the other hand, given the lower premiums, target shareholders should benefit less. Table 3 reports abnormal returns for threeand 21-day windows around the acquisition announcement for acquirers and targets, as well as synergy gains. Results are partitioned by time period and method of payment.

\section{[Please Insert Table 3 About Here]}

Panel A reports acquirer returns. Overall, public acquisitions result in a $1.50 \%$ abnormal loss for acquiring firms in the three-day window surrounding the acquisition announcement which is statistically significant at the $1 \%$ level. This is consistent with prior evidence that public acquisitions fail to create value for acquirers. ${ }^{25}$ The documented value loss can be attributed to the stock and hybrid payment subsets that result in abnormal returns of $-2.43 \%$ and $-1.55 \%$, respectively. Conversely, acquisitions paid for with cash are associated with small but positive abnormal returns. Despite the lower premiums, shareholders of acquiring companies did not earn better returns during the sixth merger wave relative to the fifth. In fact, acquirers that paid with cash created less value, reflected in the negative and statistically significant return differences between 2003-2007 and 1993-1999. This result may be associated with richer cash balances and availability of abundant liquidity in general during the sixth merger wave. Excess cash can exacerbate the free-cash flow

\footnotetext{
${ }^{24}$ This requires that the expected synergy gains from acquisitions are comparable.

${ }^{25}$ See for example, Firth (1980), Asquith (1983), Jensen and Ruback (1983), and Travlos (1987), Andrade, Mitchell, and Stafford (2001), Fuller, Netter, and Stegemoller (2002), Moeller et al. (2004), and Faccio, McConnell, and Stolin (2006). In unreported results we also establish that acquirer returns are also not statistically different between the two merger waves for deals where the target is unlisted.
} 
problem and lead to worse managerial decisions (Jensen, 1986; Harford, 1999). Moreover, acquirers have accumulated more debt in their balance sheets during the $6^{\text {th }}$ merger wave and raising more debt to pay for acquisitions can be a negative signal for investors.

There is some evidence that stock financed deals also destroyed more value for acquirer shareholders during the sixth merger wave, although results for the 21-day window do not confirm this. In general, it appears that returns to acquirers that finance acquisitions with equity or mixed payments remain in most cases negative and have not improved during the sixth merger wave.

A general explanation why mergers do not create more value during the sixth merger wave is based on investor sentiment. Rosen (2006) finds evidence that short-run abnormal returns to acquirers are higher during periods preceded by more investor over-optimism and Bouwman et al. (2009) report a positive relation between market valuations and short-run acquirer gains. Table 1 shows that 'market momentum' prior to deals in the $5^{\text {th }}$ merger wave is more pronounced than prior to deals that took place during the $6^{\text {th }}$ wave. Moreover, while both merger waves are classified as "high valuation" periods, still, inflation adjusted market $\mathrm{P} / \mathrm{E}$ ratios are significantly higher during the fifth merger wave. The thriving investor sentiment during the fifth merger wave can therefore explain why returns to acquirers were less negative for this period.

Panel B reports target announcement returns. On average, targets experience abnormal returns of $19.47 \%$, significant at the $1 \%$ level for a three-day window around the offer announcement. Gains are higher in cash deals (27.69\%) compared to stock (16.42\%) and hybrid (18.43\%) deals, although premiums for the three payment type subsets are similar. This may be because target resistance is less common and the likelihood of success lower in stock offers (Fishman, 1989; Jennings and Mazzeo, 1993). There is no evidence that target returns were lower during 2003-2007 based on the three-day window. For the 21-day window 
abnormal returns to target firms are higher for all subsets and also the differences between gains in the 2003-2007 period and the 1990s wave (or their peaks) are statistically significant in several cases. This is consistent with the evidence that the premiums paid were lower during the most recent merger wave.

If acquisitions did not create more value for both acquirer and target firm shareholders then overall acquisition gains should also not be expected to have increased after 2002. Panel $\mathrm{C}$ reports synergy gains calculated using the market value weighted average of the acquirer and target abnormal returns. Synergistic gains are positive and statistically significant at the $1 \%$ level irrespective of the return window used. However, acquisitions during the sixth merger wave created less value when cash payments were involved which clearly driven by acquirer gains for the all-cash subset (Panel A). There is no clear evidence of significant differences in combined gains from acquisitions between periods for the rest of the subsets. All in all, acquisitions during the sixth merger cycle fail to create superior value for their shareholders as well as synergy gains.

\subsection{Acquirer Winners and Losers}

In the previous section we established that investors did not perceive public acquisition announcements more favorably during the sixth merger wave compared to the 1990s. Mean and median returns to acquirers however do not accurately reflect the actual distribution of winners and losers that may convey additional information about value creation or destruction. Table 4 therefore reports the share of winners and losers as well as extreme winners and losers around the acquisition announcement within each period and payment method subset. Winners (Losers) are acquirers subject to positive (negative) 
abnormal returns. Extreme winners (losers) are acquirers that experience abnormal returns above (below) the median value of the positive (negative) return sub-set of the total sample. ${ }^{26}$

[Please Insert Table 4 About Here]

For the entire sample, there are more losers $(60.2 \%)$ than winners $(39.8 \%)$. Each of these subsets is equally split into 'moderate' and 'extreme' winners and losers. $53.3 \%$ (46.7\%) of the acquirers that paid with cash and $34.9 \%(65.1 \%)$ of those that exchanged their stock experienced positive (negative) abnormal returns. Within the winner-cash (loser-cash group) group $49.9 \%$ (only 30.5\%) are extreme winners (losers) and within the winner-stock (loser-stock) group 48.4\% (55.7\%) are extreme winners (losers). There are more extreme losers in the stock subset relative to the cash subset.

We observe significant differences in the distribution of winners and losers between the two merger waves. For instance, the percentage of winners (losers) has significantly decreased (increased) during the sixth merger wave. This may explain the fact that acquirers do not, on average, create more value for shareholders during this wave. In addition, in the fifth merger wave and during its peak in the end of the 1990s extreme winners and losers comprise a larger share than moderate winners and losers in all but the cash subset. Conversely, there was more pronounced concentration in the moderate subsets during the sixth merger wave and its peak. Difference tests show that the decrease (increase) in the share of extreme (moderate) winners in sixth merger wave, relative to the 1990s, is more pronounced for the cash sub-sample. On the other hand, the stake of extreme (moderate) losers decreased (increased) notably but differences are driven by the hybrid subset.

\footnotetext{
${ }^{26}$ The median abnormal return for the winner (loser) subset is $2.6 \%(-3.6 \%)$.
} 
In general, acquirers experienced extreme abnormal returns less often during the sixth merger wave irrespective of the method of payment used. This could reflect more efficient investor reaction to acquisition announcements during this wave. Overall, the share of winners did not increase while the share of extreme winners shrank, suggesting that there were actually fewer acquirers that created (or were expected to create) superior value for their shareholders during the sixth merger cycle.

\subsection{Multivariate Analysis}

In this section we perform multivariate tests to examine whether acquisition premiums and returns are systematically related to the time period examined after controlling for other firm and deal characteristics that may drive the results.

Table 5 reports regression estimates where the dependent variable is the acquisition premium. ${ }^{27}$ The main explanatory variable is a dummy that takes the value of one if the acquisition announcement takes place within 2003-2007 and zero otherwise. In some specifications a 2005-2006 dummy is used instead. We also include control variables that have been found to be associated with acquisition premiums. Alexandridis et al. (2010) show that premiums increase with competition in the market for corporate control. We include in our regressions a dummy variable (BID) that takes the value of one when there is one or more competing acquirers for the same target and zero otherwise. ${ }^{28}$ Premiums are also higher in tender offers (Kohers, Kohers, and Kohers, 2007) and hostile offers (Schwert, 2000). We therefore use two controls for tender offers (TEND) and hostility (HOST). The indicator variable SERIAL controls for the presence of frequent acquirers that have been associated

\footnotetext{
${ }^{27}$ Premium is defined as the ratio of the offer price to the stock price of the target four weeks prior to the acquisition announcement. Results remain similar when using a premium measure based on target returns as in Schwert (2000).

${ }^{28}$ We have also run the regressions using the alternative corporate control competition variables reported in Table 1 or a "liquidity index" as in Schlingemann, Stulz, and Walkling (2002). The sign and the significance of these variables however remain similar to the variable $B I D$.
} 
with managerial overoptimism (Billett and Qian, 2008) and, as a result, overpayment (Roll, 1986). Officer (2003) finds that acquirers pay less for financial firms. Our results in Table 2 corroborate this and also show that Hi-Tech targets receive the heftiest premiums. Accordingly, we add two binary variables for the occurrence of acquisitions involving technology $(T E C H)$ and financial (FIN) targets. We also include an inter-industry dummy (INTER) that takes the value of one when the target and the acquirer have a different 2-digit SIC code. Nathan and O'Keefe (1989) find that premiums are negatively related to the business cycle. The market run-up variable $(R U N U P)$, defined as the 6-month Buy-and-Hold return of the S\&P 500 index, starting seven months prior to the acquisition announcement, controls for this effect. Huang and Walkling (1987) find that premiums are higher in cash compared to stock acquisitions to compensate target shareholders for the immediate tax implications. Moeller et al. (2004) however document a negative relation between the occurrence of a cash offer and the premium paid. It is therefore possible that target shareholders require higher premiums in stock exchange offers to compensate them for the loss they are likely to incur from the well documented depreciation in the value of the acquirer in this case (Travlos, 1987). We thus include a dummy equal to one for stock swaps (STOCK) and zero otherwise. Moeller et al. (2004) also report that large acquirers (targets) pay (receive) higher premiums. We therefore control for acquirer (ASIZE) and target (TSIZE) size using the natural logarithms of their market capitalization one month prior to the acquisition announcement. Finally, Dong et al. (2006) show that relative acquirer and target valuations can affect the offer premium. We use the relative acquirer-to-target Tobin's Q $(R E L Q)$ to control for this effect.

We run the regressions i) for the entire sample, ii) only for the periods that comprise the two merger waves, and iii) the peak of the sixth merger wave and the peak of the fifth merger wave. We also present results for two specifications in each case as including the 
relative Q in the regressions significantly reduces our sample. In Regressions (1) and (2) the coefficient of the '2003-2007' dummy is negative and statistically significant at the $1 \%$ level corroborating that acquirers paid less for targets in the sixth merger wave. The sign and significance of most of the explanatory variables are in most cases according to the predictions of previous studies (Officer, 2003; Moeller et al., 2004; and Wang and Xie, 2009). All variables together explain $14.00 \%$ and $17.10 \%$ of the cross-sectional variation in premiums in specifications (1) and (2), respectively.

\section{[Please Insert Table 5 About Here]}

In regressions (3) to (6) we examine differences in premiums between the two merger waves and their peaks. We therefore include only 1993-1999 and 2003-2007 observations in specifications (3) and (4) and only 1998-1999 and 2005-2006 observations in specifications (5) and (6). Both wave dummies remain negative and statistically significant at the $1 \%$ level in all cases. The premiums paid during the sixth merger wave are almost nine percentage points smaller in absolute terms. Premiums are also 13\% lower during the 2005-2006 peak relative to 1998-1999. The sign and significance of the other explanatory variables are similar to regressions (1) and (2).

\section{[Please Insert Table 6 About Here]}

Table 6 presents regression estimates where the dependent variable is the 3-day CAR to acquiring firms. ${ }^{29}$ Explanatory variables are similar as in premium regressions. Asquith et al. (1983), Travlos (1987), and Moeller et al. (2004) document a negative relation between

\footnotetext{
${ }^{29}$ Results remain similar when we use a 5-, 11-, or 21-day CAR window.
} 
acquirer returns and the target-to-bidder relative size. Hence, we replace target size with relative size $(R S I Z E)$. We also include the offer premium (PREM) as an explanatory variable. The coefficients of the '2003-2007' and '2005-2006' dummies are statistically insignificant in most specifications suggesting that acquirers did not create more value for their shareholders during the sixth merger wave. In fact the negative coefficient of '2003-2007' in specification 3 statistically significant pointing to greater losses compared to the fifth merger wave. Table 7 presents the estimates of the combined CARs regressions. Overall, regression results suggest that there is no statistically significant difference in acquisition gains between the sixth merger cycle and the 1990s wave.

\section{[Please Insert Table 7 About Here]}

\subsection{Large Loss Deals}

Moeller et al. (2005) show that the extensive value destruction of M\&A deals during the fifth merger wave was primarily the result of few "large-loss" deals that represent a small part of their sample. In this section we examine whether results for the sixth merger wave are also driven by large loss deals and how the corresponding losses compare to the ones documented for the fifth merger wave.

Table 8 reports actual dollar gains/losses, cumulative abnormal returns and some other characteristics for large loss (Panel A) and non-large loss (Panel B) deals for each wave/period. Large loss are deals that result in at least $\$ 1$ bil losses (in 2007 dollars) for acquiring firms in the 3-day window surrounding the acquisition announcement. Only about $5 \%$ of all transactions are large-loss deals. There is no significant difference between the two waves in terms of the distribution of large loss deals. As a fraction of total deals more large loss deals took place during the 2000-2002 period where the markets were crashing but the weight of these deals is comparable for the two waves. While mean dollar losses are also similar across the two waves, the negative abnormal returns to acquirers in larger loss deals 
are less pronounced for the sixth merger cycle. On the other hand there is some evidence that, on average, non-large loss deals result in greater losses during this wave. This implies that the lower (or at least not higher) acquirer returns during the sixth merger wave cannot be attributed to large loss deals. ${ }^{30}$

\section{[Please Insert Table 8 About Here]}

\subsection{Acquirer Long-Run Returns}

Announcement window returns may reflect the initial perception of investors at the acquisition announcement but not actual value creation. We therefore examine whether acquirers that made acquisitions in the sixth merger wave benefit more in the long-run. In an efficient market with rational investors, and given our results in the previous sections, we would expect that acquirers did not experience superior long-term returns in the sixth merger cycle compared to the 1990s. Table 9 reports monthly estimates of calendar time abnormal returns to acquiring firms for a period of 36 months following the acquisition announcement. Abnormal returns are measured using average calendar time abnormal returns (ACTARs) and intercepts from calendar time portfolio regressions (CTPRs). ${ }^{31}$ The portfolio formation and regression processes are discussed in section 2.

\section{[Please Insert Table 9 About Here]}

\footnotetext{
${ }^{30}$ In unreported results we have also compared (non-) large loss deals across different method of payments and a 21-day event horizon and results remain similar.

${ }^{31}$ Due to the fact that the 36-month holding period could be biased by events that are affected by the financial crisis we also performed tests using 12-month event window and results remain similar. In addition, we exclude acquirers that are involved in more than one acquisition during the event window (for both 36-month and 12month holding periods) and re-run the tests. The direction and significance of the results remain similar.
} 
Based on ACTARs, acquirers in our sample experience negative abnormal returns of $9.1 \%$ in the three-year period following the acquisition announcement. This result is driven by the stock and hybrid subsets. CTPR alphas are nonetheless statistically insignificant. In general, deals announced during the sixth merger wave resulted in negative abnormal returns to acquiring companies while estimates for the fifth merger wave are in all cases statistically insignificant. CTAR (CTPR) estimates for 2005-2006 correspond to a staggering -28\% (23\%) abnormal loss in the 36 months after the acquisition proposal. ACTAR differences between the two merger waves and their peaks are only statistically significant for the stock subset implying that acquirers that paid with stock during the sixth merger wave did worse. ${ }^{32}$ Overall, acquisitions announced during the sixth merger cycle resulted in worse or at best similar performance for acquirers relative to the fifth merger cycle.

\section{Conclusion}

In this paper we present new evidence on mergers and acquisitions during the sixth merger cycle. The low financing rates and rich cash balances that resulted in liquidity awash, as well as the fact that acquirers were less overvalued relative to targets during this wave, led to more pronounced cash (and less equity) financing. The drivers of the sixth merger wave are therefore more consistent with neoclassical explanations of merger waves. In addition, the market for corporate control was less competitive, acquirers where less acquisitive and acquirer CEOs displayed less over-confidence about their ability to create superior value through M\&As. As a result premiums paid during the sixth merger wave were significantly lower than in the past, implying more rational acquisition decisions. Nonetheless, acquirers still destroyed at least as much value for their shareholders as during the fifth merger wave. This can be attributed to the higher cash balances during the sixth merger cycle that may have

\footnotetext{
${ }^{32}$ We do not compute CTAR differences as these involve regressing monthly return differences on the four factors. However, there are no common months between the periods compared here.
} 
exacerbated the free-cash flow problem and/or to the fact that investors were relatively less optimistic during this cycle compared to the 1990 s. 


\section{References}

Alexandridis, G., Petmezas, D., and Travlos, N. G., 2010, Gains from mergers and acquisitions around the world: New evidence, Financial Management 39, 1671-1695.

Andrade, G., Mitchell, M., and Stafford, E., 2001, New evidence and perspectives on mergers, Journal of Economic Perspectives 15, 103-120.

Asquith, P., 1983, Merger bids, uncertainty, and stockholder returns, Journal of Financial Economics 11, 51-83.

Asquith, P., Bruner, R. F., and Mullins, D. W., 1983, The gains to bidding firms from merger, Journal of Financial Economics 11, 121-139.

Billett, M. T., and Qian, Y., 2008, Are overconfident ceos born or made? Evidence of self-attribution bias from frequent acquirers, Management Science 54, 1037-1051.

Bouwman, C. H. S., Fuller, K., and Nain, A. S., 2009, Market valuation and acquisition quality: Empirical evidence, Review of Financial Studies 22, 633-679.

Carhart, M. M., 1997, On persistence in mutual fund performance, Journal of Finance 52, 57-82.

Dobbs, R., Goedhart, M., and Suonio, H., 2007, Are companies getting better at m\&a?, The McKinsey Quarterly 22, 7-11.

Dong, M., Hirshleifer, D., Richardson, S., and Teoh, S. H., 2006, Does investor misvaluation drive the takeover market, Journal of Finance 61, 725-762.

Faccio, M., McConnell, J. J., and Stolin, D., 2006, Returns to acquirers of listed and unlisted targets, Journal of Financial and Quantitative Analysis 41, 197-220.

Fama, E. F., and French, K. R., 1993, Common risk factors in the returns on stock and bonds, Journal of Financial Economics 33, 3-56.

Firth, M., 1980, Takeovers, shareholder returns, and the theory of the firm, Quarterly Journal of Economics 94 , 235-260.

Fishman, M. J., 1988, A theory of preemptive takeover bidding, RAND Journal of Economics 19, 88-101.

Fishman, M. J., 1989, Preemptive bidding and the role of the medium of exchange in acquisitions, Journal of Finance 44, 41-57.

Fuller, K., Netter, J., and Stegemoller, M., 2002, What do returns to acquiring firms tell us? Evidence from firms that make many acquisitions, Journal of Finance 57, 1763-1794.

Goel, A. M., and Thakor, A. V., 2010, Do envious ceos cause merger waves?, Review of Financial Studies 23, 487-517.

Harford, J., 1999, Corporate cash reserves and acquisitions, Journal of Finance 54, 1969-1997.

Harford, J., 2005, What drives merger waves?, Journal of Financial Economics 77, 529-560.

Huang, Y.-S., and Walkling, R. A., 1987, Target abnormal returns associated with acquisition announcements: Payment, acquisition form, and managerial resistance, Journal of Financial Economics 19, 329-349.

Jennings, R. H., and Mazzeo, M. A., 1993, Competing bids, target management resistance, and the structure of takeover bids, Review of Financial Studies 6, 883-909.

Jensen, M. C., 1986, Agency costs of free cash flow, corporate finance, and takeovers, American Economic Review 76, 323-329. 
Jensen, M. C., 2005, Agency costs of overvalued equity, Financial Management 34, 5-19.

Jensen, M. C., and Ruback, R. S., 1983, The market for corporate control: The scientific evidence, Journal of Financial Economics 11, 5-50.

Kohers, N., Kohers, G., and Kohers, T., 2007, Glamour, value, and the form of takeover, Journal of Economics and Business 59, 74-87.

Lang, L. H. P., Stulz, R. M., and Walkling, R. A., 1989, Managerial performance, tobin's q, and the gains from successful tender offers, Journal of Financial Economics 24, 137-154.

Malmendier, U., and Tate, G., 2008, Who makes acquisitions? Ceo overconfidence and the market's reaction, Journal of Financial Economics 89, 20-43.

Martin, K. J., 1996, The method of payment in corporate acquisitions, investment opportunities, and management ownership, Journal of Finance 51, 1227-1246.

Mitchell, M. L., and Stafford, E., 2000, Managerial decisions and long-term stock price performance, Journal of Business 73, 287-329.

Moeller, S. B., Schlingemann, F. P., and Stulz, R. M., 2004, Firm size and the gains from acquisitions, Journal of Financial Economics 73, 201-228.

Moeller, S. B., Schlingemann, F. P., and Stulz, R. M., 2005, Wealth desctruction on a massive scale? A study of acquiring-firm returns in the recent merger wave, Journal of Finance 60, 757-782.

Nathan, K. S., and O'Keefe, T. B., 1989, The rise in takeover premiums: An exploratory study, Journal of Financial Economics 23, 101-119.

Officer, M. S., 2003, Termination fees in mergers and acquisitions, Journal of Financial Economics 69, 431467.

Rhodes-Kropf, M., Robinson, D. T., and Viswanathan, S., 2005, Valuation waves and merger activity: The empirical evidence, Journal of Financial Economics 77, 561-603.

Rhodes-Kropf, M., and Viswanathan, S., 2004, Market valuation and merger waves, Journal of Finance 59, 2685-2718.

Roll, R., 1986, The hubris hypothesis of corporate takeovers, Journal of Business 59, 197-216.

Rosen, R., 2006, Merger momentum and investor sentiment: The stock market reaction to merger announcements, Journal of Business 79, 987-1017.

Schlingemann, F. P., Stulz, R. M., and Walkling, R. A., 2002, Divestitures and the liquidity of the market for corporate control, Journal of Financial Economics 64, 117-144.

Schwert, W. G., 2000, Hostility in takeovers: In the eyes of the beholder?, Journal of Finance 55, 2599-2640.

Servaes, H., 1991, Tobin's q and the gains from takeovers, Journal of Finance 46, 409-419.

Shleifer, A., and Vishny, R. W., 1991, Takeovers in the '60s and the '80s: Evidence and implications, Strategic Management Journal 12, 51-59.

Shleifer, A., and Vishny, R. W., 2003, Stock market driven acquisitions, Journal of Financial Economics 70, 295-311.

Starks, L., and Wei, K., 2004, Cross-border mergers and differences in corporate governance, Working paper University of Texas. 
Travlos, N. G., 1987, Corporate takeover bids, methods of payment, and bidding firms' stock returns, Journal of Finance 42, 943-963.

Wang, C., and Xie, F., 2009, Corporate governance transfer and synergistic gains from mergers and acquisitions, Review of Financial Studies 22, 829-858. 


\section{Table 1. Sample Statistics}

The sample includes all U.S., completed, domestic, public mergers and acquisitions reported in Thomson Financial SDC between 1993 and 2007. Acquirers are listed on NYSE, NASDAQ, or AMEX and have data available on CRSP and COMPUSTAT. The acquirer owns less that $10 \%$ of the target's shares prior to the acquisition announcement and more than $50 \%$ after the deal completion. The deal value is at least $\$ 1$ million and the size of the target is at least $1 \%$ of the size of the acquirer. Statistics are reported for the entire sample and five other sub-periods. DEAL VALUE is the transaction value. ASIZE (TSIZE) is the market capitalization (in \$ million) of the acquirer (target) one month prior the acquisition announcement. Values are in 2007 dollars. RSIZE is the target-to-bidder relative market value. Tobin's Q is the book value of assets minus the book value of common equity plus the market value of common equity over the book value of assets at the fiscal year end prior to the acquisition announcement year. RELQ is the acquirer's Tobin's Q over the target's Tobin's Q. ALL STOCK (ALL CASH) are transactions financed with pure stock (cash). STOCK (CASH) is the proportion of stock (cash) in the transaction. PREM is the offer price over the target's share price 4 weeks prior the acquisition announcement multiplied by 100 and is reported for observations between zero and 200. TCAR $(-63,126)$ is the market adjusted target return for a period $(-63,126)$ relative to the announcement day as in Schwert (2000). COMP is the share of listed firms (or the value of listed firms) on CRSP targeted in completed deals. SERIAL is the percentage of acquirers that make 2 or more public acquisitions during a 2-year period. HUBRIS is the percentage of acquiring firm managers that do not exercise vested stock options although they are 67\% in-the-money. DIVERS is the share of transactions where the acquirer and target have different 2-digit SIC codes. INTEREST is the yearly average of the Wall Street Journal's prime rate and is based on corporate loans posted by at least $70 \%$ of the 10 largest U.S. banks. DEBTLOAD is the acquirers' long-term debt-to-assets ratio divided by the median long-term debt-to-assets ratio of the corresponding industry at the fiscal year end following the acquisition announcement year. CASH RES for the Market (Sample) is the yearly average of the sum of cash and short-term investments over the sum of total assets for all U.S. listed firms (acquirers in the sample). RUNUP is the buy-and-hold return of the S\&P 500 Composite Index for a 6 month period ending one month preceding the acquisition announcement. Difference tests are based on a t-test for means and a Wilcoxon-test for medians. a, b, and c denote significance at the $1 \%$, $5 \%$, and $10 \%$ level, respectively. 


\begin{tabular}{|c|c|c|c|c|c|c|c|c|c|}
\hline & & $\begin{array}{l}\text { All } \\
\text { (1) }\end{array}$ & $\begin{array}{c}\text { 1993-1999 } \\
\text { (2) }\end{array}$ & $\begin{array}{c}\text { 1998-1999 } \\
\text { (3) }\end{array}$ & $\begin{array}{c}2000-2002 \\
(4)\end{array}$ & $\begin{array}{c}\text { 2003-2007 } \\
\text { (5) }\end{array}$ & $\begin{array}{c}2005-2006 \\
(6)\end{array}$ & $(5)-(2)$ & $(6)-(3)$ \\
\hline No of Observations & & 3,206 & 1,905 & 679 & 579 & 722 & 293 & & \\
\hline \multirow[t]{2}{*}{ DEAL VALUE } & sum & $5,336,112$ & $2,769,996$ & $1,728,726$ & $1,238,646$ & $1,327,470$ & 721,621 & & \\
\hline & mean & 1,664 & 1,454 & 2,546 & 2,139 & 1,839 & 2,463 & 385 & -83 \\
\hline \multirow[t]{2}{*}{ ASIZE } & mean & 7,839 & 5,984 & 9,785 & 10,326 & 10,738 & 13,797 & $4,754^{\mathrm{a}}$ & $4,012^{\mathrm{b}}$ \\
\hline & median & 1,283 & 1,213 & 1,788 & 1,163 & 1,716 & 1,902 & $502^{\mathrm{a}}$ & 114 \\
\hline \multirow[t]{2}{*}{ TSIZE } & mean & 1,328 & 1,164 & 1,964 & 1,498 & 1,633 & 2,338 & $469^{c}$ & $374^{\mathrm{c}}$ \\
\hline & median & 194 & 169 & 227 & 150 & 308 & 416 & $139^{\mathrm{a}}$ & $189^{\mathrm{a}}$ \\
\hline \multirow[t]{2}{*}{ RSIZE (\%) } & mean & 28.33 & 29.76 & 29.73 & 24.54 & 27.57 & 27.76 & -2.20 & -1.96 \\
\hline & median & 14.13 & 14.60 & 13.30 & 12.03 & 14.28 & 15.17 & -0.32 & 1.88 \\
\hline \multirow[t]{2}{*}{ ACQQ } & mean & 2.07 & 2.03 & 2.29 & 2.62 & 1.75 & 1.86 & $-0.28^{\mathrm{a}}$ & $-0.43^{\mathrm{a}}$ \\
\hline & median & 1.30 & 1.31 & 1.45 & 1.28 & 1.28 & 1.37 & -0.02 & $-0.08^{\mathrm{a}}$ \\
\hline \multirow[t]{2}{*}{ TARQ } & mean & 1.91 & 1.83 & 1.95 & 2.27 & 1.80 & 2.04 & -0.03 & 0.09 \\
\hline & median & 1.27 & 1.27 & 1.33 & 1.20 & 1.35 & 1.46 & 0.08 & $0.13^{\mathrm{c}}$ \\
\hline \multirow[t]{2}{*}{ RELQ } & mean & 1.27 & 1.27 & 1.34 & 1.50 & 1.11 & 1.07 & $-0.15^{\mathrm{a}}$ & $-0.27^{\mathrm{a}}$ \\
\hline & median & 1.06 & 1.06 & 1.12 & 1.12 & 1.02 & 1.01 & $-0.04^{\mathrm{a}}$ & $-0.12^{\mathrm{a}}$ \\
\hline ALL STOCK (\%) & mean & 47.88 & 58.06 & 55.67 & 43.35 & 24.65 & 23.21 & $-33.40^{\mathrm{a}}$ & $-32.46^{\mathrm{a}}$ \\
\hline STOCK (\%) & mean & 62.14 & 68.91 & 67.96 & 59.18 & 46.65 & 45.30 & $-22.26^{\mathrm{a}}$ & $-22.67^{\mathrm{a}}$ \\
\hline ALL CASH (\%) & mean & 21.24 & 16.75 & 14.87 & 21.07 & 33.24 & 33.79 & $16.50^{\mathrm{a}}$ & $18.91^{\mathrm{a}}$ \\
\hline CASH (\%) & mean & 31.85 & 24.37 & 23.57 & 33.80 & 50.03 & 51.39 & $25.66^{\mathrm{a}}$ & $27.82^{\mathrm{a}}$ \\
\hline \multirow[t]{2}{*}{ PREM (\%) } & mean & 44.43 & 44.96 & 48.33 & 51.51 & 37.85 & 36.17 & $-7.11^{\mathrm{a}}$ & $-12.16^{\mathrm{a}}$ \\
\hline & median & 36.37 & 37.73 & 42.17 & 43.71 & 30.17 & 30.20 & $-7.56^{\mathrm{a}}$ & $-11.97^{\mathrm{a}}$ \\
\hline \multirow[t]{2}{*}{ TCAR $(-63,126)$} & mean & 27.06 & 25.73 & 28.00 & 37.06 & 22.75 & 21.30 & $-2.98^{\mathrm{b}}$ & $-6.69^{\mathrm{a}}$ \\
\hline & median & 23.90 & 22.31 & 24.78 & 35.05 & 20.67 & 18.94 & $-1.63^{c}$ & $-5.83^{b}$ \\
\hline COMP - Activity (\%) & mean & 4.16 & 4.09 & 5.89 & 4.19 & 3.42 & 3.59 & - & - \\
\hline - Value Acquired (\%) & mean & 2.75 & 3.96 & 5.56 & 4.10 & 1.78 & 2.31 & - & - \\
\hline SERIAL (\%) & mean & 38.24 & 42.78 & 41.97 & 35.92 & 28.12 & 27.30 & $-14.67^{a}$ & $-14.67^{\mathrm{a}}$ \\
\hline HUBRIS (\%) & mean & 67.89 & 70.44 & 74.77 & 60.00 & 66.67 & 57.45 & -3.78 & $-17.33^{\mathrm{a}}$ \\
\hline DIVERS (\%) & mean & 30.44 & 29.82 & 30.78 & 31.43 & 31.30 & 32.76 & - & - \\
\hline INTEREST (\%) & mean & 7.10 & 7.84 & 8.18 & 6.95 & 6.14 & 7.07 & - & - \\
\hline \multirow[t]{2}{*}{ DEBTLOAD } & mean & 4.51 & 3.29 & 4.16 & 5.28 & 6.90 & 7.33 & $3.61^{\mathrm{a}}$ & $3.17^{\mathrm{a}}$ \\
\hline & median & 1.32 & 1.25 & 1.35 & 1.33 & 1.58 & 1.67 & $0.33^{\mathrm{a}}$ & $0.32^{\mathrm{a}}$ \\
\hline CASH RES - Market (\%) & mean & 8.95 & 8.05 & 8.42 & 9.02 & 10.16 & 10.33 & - & - \\
\hline - Sample (\%) & mean & 9.50 & 7.92 & 7.03 & 9.28 & 11.85 & 10.29 & - & - \\
\hline \multirow[t]{2}{*}{ RUNUP (\%) } & mean & 5.58 & 8.72 & 8.79 & -4.74 & 5.58 & 3.77 & $3.13^{\mathrm{a}}$ & $5.01^{\mathrm{a}}$ \\
\hline & median & 6.32 & 8.86 & 9.11 & -4.43 & 5.66 & 3.43 & $3.20^{\mathrm{a}}$ & $5.68^{\mathrm{a}}$ \\
\hline
\end{tabular}


Table 2. Acquisition Premiums by Sector

The sample of acquisitions meets the criteria described in Table 1. Premium is the offer price over the target's share price 4 weeks prior the acquisition announcement multiplied by 100 and is reported for observations between zero and 200. Target sectors are based on the Fama and French 5 industry classification but results for financial firms (SIC 6000-6999) are reported separately. $\mathrm{n}$ is the sample size. Difference tests are based on a t-test for means and a Wilcoxon-test for medians. a, b, and c denote significance at the $1 \%, 5 \%$, and $10 \%$ level, respectively.

\begin{tabular}{|c|c|c|c|c|c|c|c|c|c|}
\hline Industries & & $\begin{array}{l}\text { All } \\
(1)\end{array}$ & $\begin{array}{c}\text { 1993-1999 } \\
(2)\end{array}$ & $\begin{array}{c}\text { 1998-1999 } \\
(3) \\
\end{array}$ & $\begin{array}{c}2000-2002 \\
(4) \\
\end{array}$ & $\begin{array}{c}2003-2007 \\
(5) \\
\end{array}$ & $\begin{array}{c}2005-2006 \\
(6) \\
\end{array}$ & (5)-(2) & $(6)-(3)$ \\
\hline \multirow[t]{3}{*}{ All } & mean & 44.43 & 44.96 & 48.33 & 51.51 & 37.85 & 36.17 & $-7.11^{\mathrm{a}}$ & $-12.16^{\mathrm{a}}$ \\
\hline & median & 36.37 & 37.73 & 42.17 & 43.71 & 30.17 & 30.20 & $-7.56^{\mathrm{a}}$ & $-11.97^{\mathrm{a}}$ \\
\hline & $n$ & 2,416 & 1,370 & 527 & 450 & 596 & 242 & & \\
\hline \multirow[t]{4}{*}{ Consumer } & mean & 49.10 & 47.41 & 53.78 & 62.40 & 44.58 & 37.24 & -2.82 & $-16.54^{c}$ \\
\hline & median & 37.77 & 38.78 & 44.58 & 50.47 & 31.01 & 31.31 & -7.78 & $-13.27^{\mathrm{b}}$ \\
\hline & $n$ & 234 & 153 & 54 & 35 & 46 & 17 & & \\
\hline & $\%$ & 9.69 & 11.17 & 10.25 & 7.78 & 7.72 & 7.02 & & \\
\hline \multirow[t]{4}{*}{ Financials } & mean & 38.17 & 38.54 & 38.17 & 42.70 & 34.17 & 32.90 & $-4.38^{\mathrm{b}}$ & -5.28 \\
\hline & median & 32.20 & 32.44 & 31.31 & 37.74 & 27.85 & 26.05 & $-4.59^{b}$ & $-5.27^{\mathrm{c}}$ \\
\hline & $n$ & 902 & 502 & 168 & 166 & 234 & 94 & & \\
\hline & $\%$ & 37.33 & 36.64 & 31.88 & 36.89 & 39.26 & 38.84 & & \\
\hline \multirow[t]{4}{*}{ HiTec } & mean & 52.27 & 52.97 & 57.90 & 63.72 & 42.17 & 37.21 & $-10.80^{\mathrm{a}}$ & $-20.69^{a}$ \\
\hline & median & 45.00 & 49.16 & 56.40 & 54.58 & 33.93 & 32.56 & $-15.23^{\mathrm{a}}$ & $-23.85^{\mathrm{a}}$ \\
\hline & $n$ & 564 & 286 & 131 & 121 & 157 & 64 & & \\
\hline & $\%$ & 23.34 & 20.88 & 24.86 & 26.89 & 26.34 & 26.45 & & \\
\hline \multirow[t]{4}{*}{ Healthcare } & mean & 45.06 & 49.21 & 57.44 & 41.58 & 38.99 & 45.72 & $-10.21^{\mathrm{a}}$ & -11.73 \\
\hline & median & 39.08 & 40.45 & 42.68 & 39.65 & 33.62 & 40.55 & $-6.83^{\mathrm{a}}$ & -2.13 \\
\hline & $n$ & 224 & 127 & 34 & 24 & 73 & 31 & & \\
\hline & $\%$ & 9.27 & 9.27 & 6.45 & 5.33 & 12.25 & 12.81 & & \\
\hline \multirow[t]{4}{*}{ Manufacturing } & mean & 40.95 & 41.93 & 47.05 & 47.59 & 27.91 & 26.61 & $-14.02^{\mathrm{a}}$ & $-20.44^{\mathrm{a}}$ \\
\hline & median & 34.99 & 35.69 & 39.85 & 41.33 & 23.91 & 27.39 & $-11.79^{a}$ & $-12.47^{\mathrm{a}}$ \\
\hline & $n$ & 300 & 185 & 85 & 67 & 48 & 24 & & \\
\hline & $\%$ & 12.42 & 13.50 & 16.13 & 14.89 & 8.05 & 9.92 & & \\
\hline \multirow[t]{4}{*}{ Other } & mean & 49.77 & 49.91 & 47.58 & 54.32 & 44.88 & 49.16 & -5.03 & 1.59 \\
\hline & median & 43.78 & 46.06 & 46.06 & 53.22 & 31.62 & 30.87 & -14.45 & -15.19 \\
\hline & $n$ & 192 & 117 & 55 & 37 & 38 & 12 & & \\
\hline & $\%$ & 7.95 & 8.54 & 10.44 & 8.22 & 6.38 & 4.96 & & \\
\hline
\end{tabular}


Table 3. Gains to Acquirers, Targets, and the Combined Firm

The sample of acquisitions meets the criteria described in Table 1. Panel A, B, and C report acquirer, target, and combined firm cumulative abnormal returns (CARs) over a 3- and a 21-day announcement window. Market model parameters are estimated over the period (-250, -15) relative to the announcement day. Combined returns are calculated using the market value-weighted average of the acquirer and target abnormal returns where market values are measured one month prior to the acquisition announcement. $\mathrm{n}$ is the sample size. Difference tests are based on a t-test for means and a Wilcoxon-test for medians. a, b, and c denote significance at the 1\%, $5 \%$, and $10 \%$ level, respectively.

Panel A: Acquirer Returns

\begin{tabular}{|c|c|c|c|c|c|c|c|c|c|}
\hline & & $\begin{array}{l}\text { All } \\
(1)\end{array}$ & $\begin{array}{c}1993-1999 \\
(2)\end{array}$ & $\begin{array}{c}\text { 1998-1999 } \\
(3) \\
\end{array}$ & $\begin{array}{c}\text { 2000-2002 } \\
(4) \\
\end{array}$ & $\begin{array}{c}\text { 2003-2007 } \\
(5) \\
\end{array}$ & $\begin{array}{c}2005-2006 \\
(6) \\
\end{array}$ & (5)-(2) & (6)-(3) \\
\hline \multicolumn{10}{|c|}{ CARs $(-1,+1)$} \\
\hline \multirow[t]{3}{*}{ All } & mean & $-1.50^{\mathrm{a}}$ & $-1.17^{\mathrm{a}}$ & $-1.73^{\mathrm{a}}$ & $-2.36^{\mathrm{a}}$ & $-1.66^{\mathrm{a}}$ & $-1.73^{\mathrm{a}}$ & $-0.49^{c}$ & 0.00 \\
\hline & median & $-0.98^{\mathrm{a}}$ & $-0.81^{\mathrm{a}}$ & $-1.22^{\mathrm{a}}$ & $-1.69^{\mathrm{a}}$ & $-0.90^{\mathrm{a}}$ & $-1.03^{\mathrm{a}}$ & $-0.09^{c}$ & 0.19 \\
\hline & $n$ & 3,206 & 1,905 & 679 & 579 & 722 & 293 & & \\
\hline \multirow[t]{3}{*}{ Cash } & mean & $0.68^{\mathrm{a}}$ & $1.04^{\mathrm{a}}$ & $1.82^{\mathrm{a}}$ & $1.12^{\mathrm{b}}$ & -0.02 & 0.10 & $-1.06^{\mathrm{b}}$ & $-1.72^{b}$ \\
\hline & median & $0.28^{\mathrm{c}}$ & $0.49^{c}$ & $1.14^{\mathrm{b}}$ & 0.51 & -0.09 & -0.09 & $-0.58^{\mathrm{b}}$ & $-1.24^{\mathrm{b}}$ \\
\hline & $n$ & 681 & 319 & 101 & 122 & 240 & 99 & & \\
\hline \multirow[t]{3}{*}{ Stock } & mean & $-2.43^{\mathrm{a}}$ & $-1.82^{\mathrm{a}}$ & $-2.61^{\mathrm{a}}$ & $-4.48^{\mathrm{a}}$ & $-3.34^{\mathrm{a}}$ & $-2.87^{\mathrm{a}}$ & $-1.52^{\mathrm{a}}$ & -0.26 \\
\hline & median & $-1.63^{\mathrm{a}}$ & $-1.31^{\mathrm{a}}$ & $-2.19^{\mathrm{a}}$ & $-3.55^{\mathrm{a}}$ & $-2.28^{\mathrm{a}}$ & $-0.96^{b}$ & $-0.97^{\mathrm{b}}$ & 1.23 \\
\hline & $n$ & 1,535 & 1,106 & 378 & 251 & 178 & 68 & & \\
\hline \multirow[t]{3}{*}{ Hybrid } & mean & $-1.55^{\mathrm{a}}$ & $-1.16^{\mathrm{a}}$ & $-1.85^{\mathrm{a}}$ & $-1.83^{\mathrm{a}}$ & $-1.98^{\mathrm{a}}$ & $-2.54^{\mathrm{a}}$ & $-0.82^{\mathrm{c}}$ & -0.69 \\
\hline & median & $-1.27^{\mathrm{a}}$ & $-0.74^{\mathrm{a}}$ & $-1.20^{\mathrm{a}}$ & $-1.62^{\mathrm{a}}$ & $-1.53^{\mathrm{a}}$ & $-2.16^{\mathrm{a}}$ & $-0.79^{b}$ & -0.96 \\
\hline & $n$ & 990 & 480 & 200 & 206 & 304 & 126 & & \\
\hline \multicolumn{10}{|c|}{ CARs $(-10,+10)$} \\
\hline \multirow{3}{*}{ All } & mean & $-2.05^{\mathrm{a}}$ & $-2.10^{\mathrm{a}}$ & $-3.13^{\mathrm{a}}$ & $-2.07^{\mathrm{a}}$ & $-1.89^{\mathrm{a}}$ & $-1.91^{\mathrm{a}}$ & 0.22 & $1.22^{\mathrm{c}}$ \\
\hline & median & $-1.65^{\mathrm{a}}$ & $-1.74^{\mathrm{a}}$ & $-2.99^{\mathrm{a}}$ & $-1.32^{\mathrm{b}}$ & $-1.62^{\mathrm{a}}$ & $-1.96^{\mathrm{a}}$ & 0.12 & 1.03 \\
\hline & $n$ & 3,206 & 1,905 & 679 & 579 & 722 & 293 & & \\
\hline \multirow{3}{*}{ Cash } & mean & 0.31 & 0.95 & $1.74^{\mathrm{c}}$ & 0.99 & -0.86 & -0.36 & $-1.81^{\mathrm{b}}$ & -2.10 \\
\hline & median & 0.30 & 0.70 & 0.80 & 1.13 & -0.47 & -0.47 & $-1.17^{\mathrm{b}}$ & $-1.27^{\mathrm{c}}$ \\
\hline & $n$ & 681 & 319 & 101 & 122 & 240 & 99 & & \\
\hline \multirow{3}{*}{ Stock } & mean & $-2.78^{\mathrm{a}}$ & $-2.74^{\mathrm{a}}$ & $-4.41^{\mathrm{a}}$ & $-3.28^{\mathrm{a}}$ & $-2.35^{\mathrm{a}}$ & -1.94 & 0.39 & $2.47^{\mathrm{b}}$ \\
\hline & median & $-2.13^{\mathrm{a}}$ & $-2.24^{\mathrm{a}}$ & $-4.77^{\mathrm{a}}$ & $-2.09^{\mathrm{b}}$ & $-1.43^{\mathrm{b}}$ & -1.14 & 0.81 & $3.63^{\mathrm{b}}$ \\
\hline & $n$ & 1,535 & 1,106 & 378 & 251 & 178 & 68 & & \\
\hline \multirow{3}{*}{ Hybrid } & mean & $-2.55^{\mathrm{a}}$ & $-2.65^{\mathrm{a}}$ & $-3.10^{\mathrm{a}}$ & $-2.50^{\mathrm{a}}$ & $-2.43^{\mathrm{a}}$ & $-3.11^{\mathrm{a}}$ & 0.22 & -0.01 \\
\hline & median & $-2.55^{\mathrm{a}}$ & $-2.41^{\mathrm{a}}$ & $-2.73^{\mathrm{a}}$ & $-2.13^{c}$ & $-3.22^{\mathrm{a}}$ & $-3.39^{\mathrm{a}}$ & -0.80 & -0.67 \\
\hline & $n$ & 990 & 480 & 200 & 206 & 304 & 126 & & \\
\hline
\end{tabular}


Panel B: Target Returns

\begin{tabular}{|c|c|c|c|c|c|c|c|c|c|}
\hline & & $\begin{array}{l}\text { All } \\
(1)\end{array}$ & $\begin{array}{c}\text { 1993-1999 } \\
(2)\end{array}$ & $\begin{array}{c}\text { 1998-1999 } \\
(3)\end{array}$ & $\begin{array}{c}2000-2002 \\
(4)\end{array}$ & $\begin{array}{c}2003-2007 \\
(5)\end{array}$ & $\begin{array}{c}2005-2006 \\
(6) \\
\end{array}$ & (5)-(2) & $(6)-(3)$ \\
\hline \multicolumn{10}{|c|}{ CARs $(-1,+1)$} \\
\hline \multirow[t]{3}{*}{ All } & mean & $19.47^{\mathrm{a}}$ & $17.62^{\mathrm{a}}$ & $18.50^{\mathrm{a}}$ & $25.14^{\mathrm{a}}$ & $20.01^{\mathrm{a}}$ & $18.91^{\mathrm{a}}$ & $2.39^{\mathrm{a}}$ & 0.41 \\
\hline & median & $16.23^{\mathrm{a}}$ & $14.92^{\mathrm{a}}$ & $15.47^{\mathrm{a}}$ & $20.06^{\mathrm{a}}$ & $16.67^{\mathrm{a}}$ & $16.24^{\mathrm{a}}$ & $1.75^{\mathrm{a}}$ & 0.77 \\
\hline & $n$ & 2,509 & 1,503 & 549 & 436 & 570 & 224 & & \\
\hline \multirow[t]{3}{*}{ Cash } & mean & $27.69^{\mathrm{a}}$ & $25.84^{\mathrm{a}}$ & $27.47^{\mathrm{a}}$ & $35.63^{\mathrm{a}}$ & $26.79^{\mathrm{a}}$ & $24.12^{\mathrm{a}}$ & 0.94 & -3.36 \\
\hline & median & $23.00^{\mathrm{a}}$ & $20.47^{\mathrm{a}}$ & $21.17^{\mathrm{a}}$ & $32.20^{\mathrm{a}}$ & $21.95^{\mathrm{a}}$ & $19.74^{\mathrm{a}}$ & 1.48 & -1.43 \\
\hline & $n$ & 541 & 258 & 81 & 83 & 200 & 83 & & \\
\hline \multirow[t]{3}{*}{ Stock } & mean & $16.42^{\mathrm{a}}$ & $15.23^{\mathrm{a}}$ & $16.78^{\mathrm{a}}$ & $23.03^{\mathrm{a}}$ & $14.58^{\mathrm{a}}$ & $15.87^{\mathrm{a}}$ & -0.66 & -0.92 \\
\hline & median & $13.39^{\mathrm{a}}$ & $12.97^{\mathrm{a}}$ & $14.33^{\mathrm{a}}$ & $18.79^{\mathrm{a}}$ & $12.02^{\mathrm{a}}$ & $15.60^{\mathrm{a}}$ & -0.95 & 1.27 \\
\hline & $n$ & 1,192 & 859 & 300 & 193 & 140 & 49 & & \\
\hline \multirow[t]{3}{*}{ Hybrid } & mean & $18.43^{\mathrm{a}}$ & $17.43^{\mathrm{a}}$ & $17.24^{\mathrm{a}}$ & $22.24^{\mathrm{a}}$ & $17.43^{\mathrm{a}}$ & $15.84^{\mathrm{a}}$ & 0.00 & -1.41 \\
\hline & median & $14.88^{\mathrm{a}}$ & $14.86^{\mathrm{a}}$ & $14.80^{\mathrm{a}}$ & $16.09^{\mathrm{a}}$ & $14.87^{\mathrm{a}}$ & $14.02^{\mathrm{a}}$ & 0.01 & -0.78 \\
\hline & $n$ & 776 & 386 & 168 & 160 & 230 & 92 & & \\
\hline \multicolumn{10}{|c|}{ CARs $(-10,+10)$} \\
\hline \multirow[t]{3}{*}{ All } & mean & $23.31^{\mathrm{a}}$ & $22.10^{\mathrm{a}}$ & $24.37^{\mathrm{a}}$ & $29.36^{\mathrm{a}}$ & $21.84^{\mathrm{a}}$ & $21.35^{\mathrm{a}}$ & -0.25 & $-3.03^{c}$ \\
\hline & median & $20.27^{\mathrm{a}}$ & $19.80^{\mathrm{a}}$ & $21.79^{\mathrm{a}}$ & $25.91^{\mathrm{a}}$ & $18.77^{\mathrm{a}}$ & $17.71^{\mathrm{a}}$ & -1.04 & -4.08 \\
\hline & $n$ & 2,509 & 1,501 & 544 & 439 & 569 & 225 & & \\
\hline \multirow[t]{3}{*}{ Cash } & mean & $31.12^{\mathrm{a}}$ & $30.00^{\mathrm{a}}$ & $34.40^{\mathrm{a}}$ & $41.64^{\mathrm{a}}$ & $28.10^{\mathrm{a}}$ & $25.62^{\mathrm{a}}$ & -1.90 & $-8.78^{b}$ \\
\hline & median & $26.95^{\mathrm{a}}$ & $26.83^{\mathrm{a}}$ & $28.00^{\mathrm{a}}$ & $39.32^{\mathrm{a}}$ & $23.66^{\mathrm{a}}$ & $20.75^{\mathrm{a}}$ & -3.17 & $-7.25^{\mathrm{b}}$ \\
\hline & $n$ & 544 & 260 & 81 & 85 & 199 & 83 & & \\
\hline \multirow[t]{3}{*}{ Stock } & mean & $20.51^{\mathrm{a}}$ & $19.44^{\mathrm{a}}$ & $21.96^{\mathrm{a}}$ & $28.51^{\mathrm{a}}$ & $16.13^{\mathrm{a}}$ & $16.97^{\mathrm{a}}$ & $-3.30^{c}$ & -4.99 \\
\hline & median & $18.04^{\mathrm{a}}$ & $17.45^{\mathrm{a}}$ & $20.80^{\mathrm{a}}$ & $25.91^{\mathrm{a}}$ & $14.57^{\mathrm{a}}$ & $13.87^{\mathrm{a}}$ & $-2.88^{\mathrm{c}}$ & -6.94 \\
\hline & $n$ & 1,188 & 857 & 296 & 191 & 140 & 50 & & \\
\hline \multirow[t]{3}{*}{ Hybrid } & mean & $22.13^{\mathrm{a}}$ & $22.69^{\mathrm{a}}$ & $23.78^{\mathrm{a}}$ & $23.95^{\mathrm{a}}$ & $19.91^{\mathrm{a}}$ & $19.87^{\mathrm{a}}$ & $-2.78^{\mathrm{c}}$ & -3.91 \\
\hline & median & $18.81^{\mathrm{a}}$ & $20.52^{\mathrm{a}}$ & $20.65^{\mathrm{a}}$ & $18.77^{\mathrm{a}}$ & $17.62^{\mathrm{a}}$ & $16.67^{\mathrm{a}}$ & -2.91 & -3.98 \\
\hline & $n$ & 777 & 384 & 167 & 163 & 230 & 92 & & \\
\hline
\end{tabular}


Panel C: Combined Returns

\begin{tabular}{|c|c|c|c|c|c|c|c|c|c|}
\hline & & $\begin{array}{l}\text { All } \\
(1) \\
\end{array}$ & $\begin{array}{c}\text { 1993-1999 } \\
(2) \\
\end{array}$ & $\begin{array}{c}\text { 1998-1999 } \\
(3) \\
\end{array}$ & $\begin{array}{c}2000-2002 \\
(4) \\
\end{array}$ & $\begin{array}{c}2003-2007 \\
(5) \\
\end{array}$ & $\begin{array}{c}2005-2006 \\
(6) \\
\end{array}$ & (5)-(2) & (6)-(3) \\
\hline \multicolumn{10}{|c|}{ CARs $(-1,+1)$} \\
\hline \multirow[t]{3}{*}{ All } & mean & $1.12^{\mathrm{a}}$ & $1.30^{\mathrm{a}}$ & $0.91^{\mathrm{a}}$ & $0.52^{\mathrm{c}}$ & $1.09^{\mathrm{a}}$ & $1.15^{\mathrm{a}}$ & -0.21 & 0.24 \\
\hline & median & $0.74^{\mathrm{a}}$ & $0.85^{\mathrm{a}}$ & 0.35 & 0.36 & $0.64^{\mathrm{a}}$ & $0.67^{\mathrm{c}}$ & -0.21 & 0.31 \\
\hline & $n$ & 2,509 & 1,498 & 545 & 442 & 569 & 222 & & \\
\hline \multirow[t]{3}{*}{ Cash } & mean & $2.58^{\mathrm{a}}$ & $2.88^{\mathrm{a}}$ & $3.02^{\mathrm{a}}$ & $3.31^{\mathrm{a}}$ & $1.87^{\mathrm{a}}$ & $1.82^{\mathrm{a}}$ & $-1.00^{\mathrm{b}}$ & -1.20 \\
\hline & median & $1.71^{\mathrm{a}}$ & $1.99^{\mathrm{a}}$ & $2.44^{\mathrm{a}}$ & $2.78^{\mathrm{a}}$ & $1.19^{\mathrm{a}}$ & $0.91^{\mathrm{b}}$ & $-0.80^{\mathrm{b}}$ & -1.53 \\
\hline & $n$ & 551 & 259 & 82 & 90 & 202 & 83 & & \\
\hline \multirow[t]{3}{*}{ Stock } & mean & 0.12 & $0.40^{\mathrm{b}}$ & -0.03 & $-0.94^{b}$ & -0.17 & 0.42 & -0.57 & 0.45 \\
\hline & median & -0.04 & 0.09 & -0.48 & $-0.52^{c}$ & -0.52 & 0.28 & -0.60 & 0.76 \\
\hline & $n$ & 1,186 & 856 & 296 & 192 & 138 & 47 & & \\
\hline \multirow[t]{3}{*}{ Hybrid } & mean & $1.60^{\mathrm{a}}$ & $2.24^{\mathrm{a}}$ & $1.53^{\mathrm{a}}$ & 0.71 & $1.17^{\mathrm{a}}$ & $0.90^{\mathrm{c}}$ & $-1.07^{\mathrm{b}}$ & -0.63 \\
\hline & median & $0.89^{\mathrm{a}}$ & $1.49^{\mathrm{a}}$ & $0.51^{\mathrm{c}}$ & 0.07 & 0.54 & 0.42 & $-0.95^{\mathrm{b}}$ & -0.09 \\
\hline & $n$ & 772 & 383 & 167 & 160 & 229 & 92 & & \\
\hline \multicolumn{10}{|c|}{ CARs $(-10,+10)$} \\
\hline \multirow[t]{3}{*}{ All } & mean & $1.12^{\mathrm{a}}$ & $1.05^{\mathrm{a}}$ & 0.30 & $1.10^{\mathrm{c}}$ & $1.31^{\mathrm{a}}$ & $1.23^{\mathrm{b}}$ & 0.26 & 0.93 \\
\hline & median & $0.79^{\mathrm{a}}$ & $0.56^{\mathrm{b}}$ & 0.17 & $1.69^{\mathrm{a}}$ & $0.57^{\mathrm{a}}$ & 0.33 & 0.01 & 0.17 \\
\hline & $n$ & 2,509 & 1,503 & 546 & 436 & 570 & 225 & & \\
\hline \multirow[t]{3}{*}{ Cash } & mean & $2.85^{\mathrm{a}}$ & $3.72^{\mathrm{a}}$ & $3.92^{\mathrm{a}}$ & $3.82^{\mathrm{a}}$ & $1.29^{\mathrm{b}}$ & 0.92 & $-2.43^{\mathrm{a}}$ & $-3.00^{b}$ \\
\hline & median & $2.59^{\mathrm{a}}$ & $3.30^{\mathrm{a}}$ & $3.55^{\mathrm{a}}$ & $4.30^{\mathrm{a}}$ & $1.22^{\mathrm{b}}$ & 1.04 & $-2.08^{\mathrm{a}}$ & $-2.51^{b}$ \\
\hline & $n$ & 553 & 261 & 82 & 90 & 202 & 83 & & \\
\hline \multirow[t]{3}{*}{ Stock } & mean & -0.18 & -0.29 & $-1.46^{\mathrm{b}}$ & -0.54 & 0.97 & 1.31 & 1.25 & 2.76 \\
\hline & median & -0.36 & -0.43 & $-1.32^{\mathrm{b}}$ & 0.00 & -0.15 & 1.06 & 0.28 & $2.38^{\mathrm{c}}$ \\
\hline & $n$ & 1,181 & 858 & 298 & 185 & 138 & 50 & & \\
\hline \multirow[t]{3}{*}{ Hybrid } & mean & $1.85^{\mathrm{a}}$ & $2.21^{\mathrm{a}}$ & $1.66^{\mathrm{c}}$ & 1.46 & $1.53^{\mathrm{a}}$ & $1.48^{\mathrm{c}}$ & -0.68 & -0.19 \\
\hline & median & $1.36^{\mathrm{a}}$ & $1.67^{\mathrm{a}}$ & 0.95 & $2.96^{\mathrm{b}}$ & 0.52 & -0.42 & -1.15 & -1.37 \\
\hline & $n$ & 775 & 384 & 166 & 161 & 230 & 92 & & \\
\hline
\end{tabular}




\section{Table 4. Winners and Losers}

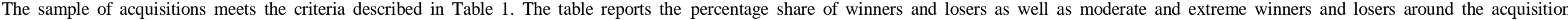

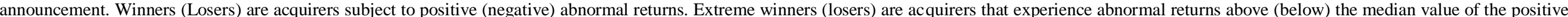

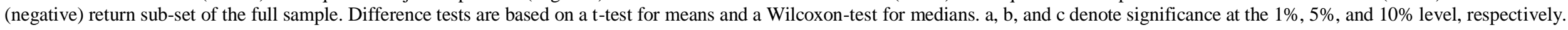

\begin{tabular}{|c|c|c|c|c|c|c|c|c|c|c|c|c|c|c|c|c|c|c|c|c|c|c|}
\hline & & & $\begin{array}{l}\text { All } \\
(1) \\
\end{array}$ & & & $\begin{array}{c}1993-199 \\
(2) \\
\end{array}$ & & & $\begin{array}{c}\text { 1998-199 } \\
\text { (3) } \\
\end{array}$ & & & $\begin{array}{c}2003-200 \\
(4) \\
\end{array}$ & & & $\begin{array}{r}2005-200 \\
\quad(5) \\
\end{array}$ & & & (4)-(2) & & & (5)-(3) & \\
\hline & & All & Moder & Extr & All & Moder & Extr & All & Moder & Extr & All & Moder & Extr & All & Moder & Extr & All & Moder & Extr & All & Moder & Extr \\
\hline \multirow{5}{*}{$\begin{array}{l}\text { Winners } \\
\text { CAR>0 }\end{array}$} & \multirow{3}{*}{$\begin{array}{c}\text { All } \\
\text { Cash }\end{array}$} & & {$[0,2.6]$} & $>2.6$ & & {$[0,2.6]$} & $>2.6$ & & {$[0,2.6]$} & $>2.6$ & & {$[0,2.6]$} & $>2.6$ & & {$[0,2.6]$} & $>2.6$ & & {$[0,2.6]$} & $>2.6$ & & {$[0,2.6]$} & $>2.6$ \\
\hline & & 39.8 & 50.0 & 50.0 & 42.0 & 50.3 & 49.7 & 38.6 & 42.0 & 58.0 & 36.8 & 58.6 & 41.4 & 34.8 & 57.8 & 42.2 & $-5.2^{\mathrm{b}}$ & $8.3^{\mathrm{b}}$ & $-8.3^{b}$ & -3.8 & $15.8^{\mathrm{a}}$ & $-15.8^{\mathrm{a}}$ \\
\hline & & 53.3 & 50.1 & 49.9 & 55.8 & 48.9 & 51.1 & 62.4 & 42.9 & 57.1 & 48.3 & 59.5 & 40.5 & 47.5 & 57.5 & 42.5 & $-7.5^{\mathrm{c}}$ & $10.6^{\mathrm{c}}$ & $-10.6^{c}$ & $-14.9^{\mathrm{b}}$ & 14.6 & -14.6 \\
\hline & \multirow{3}{*}{$\begin{array}{c}\text { Stock } \\
\text { Hybrid }\end{array}$} & 34.9 & 51.6 & 48.4 & 37.4 & 52.4 & 47.6 & 31.8 & 42.5 & 57.5 & 30.9 & 63.6 & 36.4 & 36.8 & 56.0 & 44.0 & $-6.5^{\mathrm{c}}$ & 11.2 & -11.2 & 5.0 & 13.5 & -13.5 \\
\hline & & 38.3 & 47.8 & 52.2 & 43.3 & 47.1 & 52.9 & 39.5 & 40.5 & 59.5 & 31.2 & 54.8 & 45.2 & 23.8 & 60.0 & 40.0 & $-12.0^{\mathrm{a}}$ & 7.7 & -7.7 & $-15.7^{\mathrm{a}}$ & $19.5^{\mathrm{c}}$ & $-19.5^{\circ}$ \\
\hline \multirow{5}{*}{$\begin{array}{l}\text { Losers } \\
\text { CAR }<0\end{array}$} & & & {$[-3.6,0)$} & $<-3.6$ & & {$[-3.6,0)$} & $<-3.6$ & & {$[-3.6,0)$} & $<-3.6$ & & {$[-3.6,0)$} & $<-3.6$ & & {$[-3.6,0)$} & $<-3.6$ & & {$[-3.6,0)$} & $<-3.6$ & & {$[-3.6,0)$} & $<-3.6$ \\
\hline & All & 60.2 & 50.0 & 50.0 & 58.0 & 50.2 & 49.8 & 61.4 & 43.7 & 56.3 & 63.2 & 55.7 & 44.3 & 65.2 & 57.1 & 42.9 & $5.2^{\mathrm{b}}$ & $5.5^{\mathrm{b}}$ & $-5.5^{\mathrm{b}}$ & 3.8 & $13.4^{\mathrm{a}}$ & $-13.4^{\mathrm{a}}$ \\
\hline & Cash & 46.7 & 69.5 & 30.5 & 44.2 & 70.9 & 29.1 & 37.6 & 65.8 & 34.2 & 51.7 & 71.0 & 29.0 & 52.5 & 75.0 & 25.0 & $7.5^{\mathrm{c}}$ & 0.1 & -0.1 & $14.9^{\mathrm{b}}$ & 9.2 & -9.2 \\
\hline & Stock & 65.1 & 44.3 & 55.7 & 62.6 & 47.4 & 52.6 & 68.2 & 41.1 & 58.9 & 69.1 & 42.3 & 57.7 & 63.2 & 34.8 & 65.2 & $6.5^{\mathrm{c}}$ & -5.1 & 5.1 & -5.0 & -6.3 & 6.3 \\
\hline & Hybrid & 61.7 & 49.3 & 50.7 & 56.7 & 46.7 & 53.3 & 60.5 & 42.2 & 57.8 & 68.8 & 55.5 & 44.5 & 76.2 & 57.3 & 42.7 & $12.0^{\mathrm{a}}$ & $8.8^{\mathrm{c}}$ & $-8.8^{\mathrm{c}}$ & $15.7^{\mathrm{a}}$ & $15.1^{\mathrm{b}}$ & $-15.1^{\mathrm{b}}$ \\
\hline
\end{tabular}


The sample of acquisitions meets the criteria described in Table 1. The dependent variable is the offer premium; offer price over the target's share price 4 weeks prior the acquisition announcement. Premium observations between zero and two are excluded. Regressions are performed for i) the entire sample (specifications 1-2), ii) for 1993-1999 and 2003-2007 observations only (specifications 3-4), and iii) for 1998-1999 and 2005-2006 observations only (specifications 5-6). 20032007 is a dummy variable that takes the value of 1 for acquisitions announced between 2003 and 2007, and zero otherwise. 2005-2006 is a binary variable that takes the value of 1 for acquisitions announced between 2005 and 2006, and zero otherwise. BID is a dummy variable equal to 1 if the target firm received at least one additional bid from a third party when the initial bid was still under consideration, and zero otherwise. TEND is a dummy equal to 1 if a tender offer was made to target shareholders and zero otherwise. SERIAL is a dummy equal to 1 if the acquiring firm has made 2 or more acquisitions within 2 consecutive years, and zero otherwise. HOST is a dummy equal to 1 if the acquirer makes an offer to target shareholders bypassing target management and zero otherwise. INTER is a dummy equal to 1 if the acquiring and the target firms have a different 2-digit SIC code, and zero otherwise. FIN is a dummy equal to 1 if the target is a financial firm with SIC code between 6000-6999, and zero otherwise. TECH is a dummy equal to 1 if the target firm is in a high-tech industry, and zero otherwise. RUNUP is the buy-and-hold return of the S\&P 500 Composite Index for a 6 month period ending one month preceding the acquisition announcement. STOCK is a dummy variable if the transaction was financed $100 \%$ with stock. ASIZE (TSIZE) is the natural logarithm of the acquirer's (target's) market capitalization one month prior to the acquisition announcement. RELQ is the acquirer's Tobin's Q over target's Tobin's Q. Tobin's Q is defined as the book value of assets plus market value of equity minus the book value of equity over the book value of assets at the fiscal year end pri or to the announcement year. $\mathrm{N}$ is the number of observations in each regression and Adj. $\mathrm{R}^{2}$ is the adjusted $\mathrm{R}$-squared. $\mathrm{p}$-values are reported below regression estimates. a, b, and c denote significance at the $1 \%, 5 \%$, and $10 \%$ level, respectively.

\begin{tabular}{|c|c|c|c|c|c|c|}
\hline & & & 1993-199 & 003-2007 & 1998-199 & 005-2006 \\
\hline & (1) & (2) & (3) & (4) & (5) & (6) \\
\hline Intercept & $0.5660^{\mathrm{a}}$ & $0.5368^{\mathrm{a}}$ & $0.5681^{\mathrm{a}}$ & $0.5357^{\mathrm{a}}$ & $0.6079^{\mathrm{a}}$ & $0.6488^{\mathrm{a}}$ \\
\hline & 0.000 & 0.000 & 0.000 & 0.000 & 0.000 & 0.000 \\
\hline 2003-2007 & $-0.0892^{\mathrm{a}}$ & $-0.0887^{\mathrm{a}}$ & $-0.0850^{\mathrm{a}}$ & $-0.0873^{\mathrm{a}}$ & & \\
\hline & 0.000 & 0.000 & 0.000 & 0.000 & & \\
\hline 2005-2006 & & & & & $-0.1052^{\mathrm{a}}$ & $-0.1264^{\mathrm{a}}$ \\
\hline & & & & & 0.000 & 0.000 \\
\hline BID & $0.1373^{\mathrm{a}}$ & $0.1128^{\mathrm{a}}$ & $0.1611^{\mathrm{a}}$ & $0.1304^{\mathrm{a}}$ & 0.0689 & 0.0761 \\
\hline & 0.000 & 0.003 & 0.000 & 0.002 & 0.242 & 0.235 \\
\hline TEND & 0.0292 & 0.0340 & 0.0296 & 0.0139 & 0.0259 & 0.0528 \\
\hline & 0.143 & 0.164 & 0.173 & 0.620 & 0.470 & 0.254 \\
\hline SERIAL & 0.0224 & $0.0284^{c}$ & 0.0185 & 0.0266 & 0.0259 & $0.0539^{c}$ \\
\hline & 0.112 & 0.083 & 0.221 & 0.132 & 0.296 & 0.055 \\
\hline HOST & $0.1728^{\mathrm{a}}$ & $0.2000^{\mathrm{a}}$ & $0.1797^{\mathrm{a}}$ & $0.2254^{\mathrm{a}}$ & 0.0656 & 0.0496 \\
\hline & 0.002 & 0.001 & 0.004 & 0.001 & 0.563 & 0.672 \\
\hline INTER & 0.0191 & 0.0249 & 0.0216 & 0.0168 & 0.0200 & 0.0206 \\
\hline & 0.166 & 0.124 & 0.139 & 0.332 & 0.401 & 0.445 \\
\hline FIN & $-0.1034^{\mathrm{a}}$ & $-0.0899^{a}$ & $-0.0956^{\mathrm{a}}$ & $-0.0924^{\mathrm{a}}$ & $-0.1465^{\mathrm{a}}$ & $-0.1278^{a}$ \\
\hline & 0.000 & 0.000 & 0.000 & 0.000 & 0.000 & 0.000 \\
\hline TECH & $0.0559^{\mathrm{a}}$ & $0.0421^{\mathrm{b}}$ & $0.0437^{\mathrm{b}}$ & $0.0335^{\mathrm{c}}$ & 0.0288 & 0.0509 \\
\hline & 0.001 & 0.026 & 0.012 & 0.098 & 0.293 & 0.107 \\
\hline RUNUP & $-0.1673^{b}$ & -0.1106 & -0.1448 & -0.1480 & -0.0742 & -0.1728 \\
\hline & 0.018 & 0.179 & 0.142 & 0.217 & 0.630 & 0.357 \\
\hline STOCK & 0.0088 & 0.0059 & 0.0003 & -0.0015 & 0.0377 & 0.0317 \\
\hline & 0.534 & 0.721 & 0.984 & 0.934 & 0.140 & 0.268 \\
\hline ASIZE & $0.0360^{\mathrm{a}}$ & $0.0345^{\mathrm{a}}$ & $0.0327^{\mathrm{a}}$ & $0.0331^{\mathrm{a}}$ & $0.0353^{\mathrm{a}}$ & $0.0292^{\mathrm{a}}$ \\
\hline & 0.000 & 0.000 & 0.000 & 0.000 & 0.000 & 0.003 \\
\hline TSIZE & $-0.0695^{\mathrm{a}}$ & $-0.0692^{\mathrm{a}}$ & $-0.0659^{a}$ & $-0.0658^{\mathrm{a}}$ & $-0.0715^{\mathrm{a}}$ & $-0.0714^{a}$ \\
\hline & 0.000 & 0.000 & 0.000 & 0.000 & 0.000 & 0.000 \\
\hline RELQ & & $0.0294^{\mathrm{a}}$ & & $0.0310^{\mathrm{a}}$ & & 0.0088 \\
\hline & & 0.002 & & 0.007 & & 0.572 \\
\hline $\mathbf{N}$ & 2,264 & 1,479 & 1,855 & 1,164 & 720 & 494 \\
\hline $\operatorname{Adj.} \mathbf{R}^{2}(\%)$ & 14.00 & 17.10 & 13.10 & 15.88 & 16.24 & 19.55 \\
\hline
\end{tabular}


The dependent variable is the 3-day acquirer cumulative abnormal return (CAR) where market model parameters are estimated over the period $(-250,-15)$ relative to the announcement day. The sample meets the criteria described in Table 1. Regressions are performed for i) the entire sample (specifications 1-2), ii) for 1993-1999 and 2003-2007 observations only (specifications 3-4), and iii) for 1998-1999 and 2005-2006 observations only (specifications 5-6). 2003-2007 is a dummy variable that takes the value of 1 for acquisitions announced between 2003 and 2007, and zero otherwise. 2005-2006 is a binary variable that takes the value of 1 for acquisitions announced between 2005 and 2006, and zero otherwise. RSIZE is the natural logarithm of the market value of the target over the market value of the acquirer, measured one month prior to the acquisition announcement. PREM is the offer price over the target's share price 4 weeks prior the acquisition announcement multiplied by 100 and is reported for observations between zero and 200. The remaining variables are defined in Table 5. N is the number of observations in each regression and Adj. $\mathrm{R}^{2}$ is the adjusted R-squared. p-values are reported below regression estimates. a, b, and c denote significance at the $1 \%, 5 \%$, and $10 \%$ level, respectively.

\begin{tabular}{|c|c|c|c|c|c|c|}
\hline & \multicolumn{2}{|c|}{ All } & \multicolumn{2}{|c|}{$1993-1999 \& 2003-2007$} & \multicolumn{2}{|c|}{$1998-1999 \& 2005-2006$} \\
\hline & (1) & (2) & (3) & (4) & (5) & (6) \\
\hline \multirow[t]{2}{*}{ Intercept } & 0.0067 & 0.0098 & 0.0022 & 0.0017 & -0.0033 & -0.0141 \\
\hline & 0.173 & 0.287 & 0.685 & 0.875 & 0.732 & 0.419 \\
\hline \multirow[t]{2}{*}{ 2003-2007 } & -0.0045 & -0.0038 & $-0.0064^{\mathrm{b}}$ & -0.0060 & & \\
\hline & 0.115 & 0.297 & 0.028 & 0.142 & & \\
\hline \multirow[t]{2}{*}{$2005-2006$} & & & & & -0.0013 & 0.0048 \\
\hline & & & & & 0.802 & 0.497 \\
\hline \multirow[t]{2}{*}{ BID } & $-0.0115^{\mathrm{c}}$ & -0.0065 & -0.0031 & -0.0049 & -0.0002 & -0.0006 \\
\hline & 0.083 & 0.441 & 0.667 & 0.611 & 0.987 & 0.966 \\
\hline \multirow[t]{2}{*}{ TEND } & $0.0202^{\mathrm{a}}$ & $0.0143^{\mathrm{a}}$ & $0.0197^{\mathrm{a}}$ & $0.0157^{\mathrm{b}}$ & $0.0189^{\mathrm{b}}$ & $0.0315^{\mathrm{a}}$ \\
\hline & 0.000 & 0.008 & 0.000 & 0.014 & 0.011 & 0.004 \\
\hline \multirow[t]{2}{*}{ SERIAL } & 0.0029 & -0.0041 & 0.0032 & -0.0038 & $0.0080^{c}$ & 0.0039 \\
\hline & 0.254 & 0.256 & 0.234 & 0.348 & 0.098 & 0.547 \\
\hline \multirow[t]{2}{*}{ HOST } & 0.0008 & 0.0197 & 0.0002 & 0.0183 & -0.0141 & 0.0056 \\
\hline & 0.942 & 0.125 & 0.984 & 0.215 & 0.583 & 0.839 \\
\hline \multirow[t]{2}{*}{ INTER } & 0.0040 & 0.0035 & 0.0033 & 0.0054 & 0.0051 & 0.0049 \\
\hline & 0.103 & 0.317 & 0.209 & 0.172 & 0.266 & 0.436 \\
\hline \multirow[t]{2}{*}{ FIN } & 0.0032 & -0.0022 & 0.0015 & -0.0038 & -0.0019 & -0.0083 \\
\hline & 0.247 & 0.595 & 0.615 & 0.396 & 0.715 & 0.266 \\
\hline \multirow[t]{2}{*}{ ТЕСН } & $-0.0169^{\mathrm{a}}$ & $-0.0151^{\mathrm{a}}$ & $-0.0155^{\mathrm{a}}$ & $-0.0157^{\mathrm{a}}$ & $-0.0118^{b}$ & -0.0094 \\
\hline & 0.000 & 0.000 & 0.000 & 0.001 & 0.033 & 0.201 \\
\hline \multirow[t]{2}{*}{ RUNUP } & $0.0234^{\mathrm{c}}$ & $0.0566^{\mathrm{a}}$ & 0.0080 & 0.0284 & 0.0065 & 0.0391 \\
\hline & 0.061 & 0.002 & 0.646 & 0.296 & 0.827 & 0.372 \\
\hline \multirow[t]{2}{*}{ STOCK } & $-0.0165^{\mathrm{a}}$ & $-0.0179^{\mathrm{a}}$ & $-0.0130^{\mathrm{a}}$ & $-0.0151^{\mathrm{a}}$ & $-0.0143^{\mathrm{a}}$ & -0.0090 \\
\hline & 0.000 & 0.000 & 0.000 & 0.000 & 0.003 & 0.179 \\
\hline \multirow[t]{2}{*}{ ASIZE } & $-0.0022^{\mathrm{a}}$ & $-0.0036^{\mathrm{a}}$ & $-0.0013^{\mathrm{b}}$ & $-0.0020^{\mathrm{c}}$ & -0.0014 & -0.0020 \\
\hline & 0.000 & 0.001 & 0.045 & 0.096 & 0.217 & 0.285 \\
\hline \multirow[t]{2}{*}{ RSIZE } & & $-0.0119^{\mathrm{a}}$ & & $-0.0097^{\mathrm{a}}$ & & $-0.0097^{\mathrm{a}}$ \\
\hline & & 0.000 & & 0.000 & & 0.000 \\
\hline \multirow[t]{2}{*}{ PREM } & & $-0.0283^{\mathrm{a}}$ & & $-0.0266^{\mathrm{a}}$ & & $-0.0293^{\mathrm{a}}$ \\
\hline & & 0.000 & & 0.000 & & 0.006 \\
\hline \multirow[t]{2}{*}{ RELQ } & & $-0.0055^{\mathrm{a}}$ & & -0.0036 & & -0.0019 \\
\hline & & 0.008 & & 0.172 & & 0.604 \\
\hline $\mathbf{N}$ & 3,206 & 1,479 & 2,627 & 1,164 & 972 & 494 \\
\hline Adj. $\mathbf{R}^{2}(\%)$ & 4.69 & 9.36 & 3.64 & 6.94 & 2.42 & 5.56 \\
\hline
\end{tabular}


The dependent variable is the 3-day combined acquirer and target cumulative abnormal return (CAR) where market model parameters are estimated over the period $(-250,-15)$ relative to the announcement day. Combined returns are calculated using the market value-weighted average of the acquirer and target abnormal returns where market values are measured one month prior to the acquisition announcement. The sample meets the criteria described in Table 1 and the target firm is listed on CRSP and COMPUSTAT. Regressions are performed for i) the entire sample (specifications 1-2), ii) for 1993-1999 and 2003-2007 observations only (specifications 3-4), and iii) for 1998-1999 and 2005-2006 observations only (specifications 56). 2003-2007 is a dummy variable that takes the value of 1 for acquisitions announced between 2003 and 2007, and zero otherwise. 2005-2006 is a dummy variable that takes the value of 1 for acquisitions announced between 2005 and 2006, and zero otherwise. RSIZE is the natural logarithm of the market value of the target over the market value of the acquirer, measured one month prior to the acquisition announcement. PREM is the offer price over the target's share price 4 weeks prior the acquisition announcement multiplied by 100 and is reported for observations between zero and 200. The remaining variables are defined in Table 5. $\mathrm{N}$ is the number of observations in each regression and Adj. $\mathrm{R}^{2}$ is the adjusted R-squared. $\mathrm{p}$ values are reported below regression estimates. a, b, and c denote significance at the $1 \%, 5 \%$, and $10 \%$ level, respectively.

\begin{tabular}{|c|c|c|c|c|c|c|}
\hline & \multicolumn{2}{|c|}{ All } & \multicolumn{2}{|c|}{$1993-1999 \& 2003-2007$} & \multicolumn{2}{|c|}{$1998-1999 \& 2005-2006$} \\
\hline & (1) & (2) & (3) & (4) & (5) & (6) \\
\hline \multirow[t]{2}{*}{ Intercept } & $0.0337^{\mathrm{a}}$ & $0.0327^{\mathrm{a}}$ & $0.0377^{\mathrm{a}}$ & $0.0333^{\mathrm{a}}$ & $0.0284^{\mathrm{a}}$ & $0.0189^{\mathrm{b}}$ \\
\hline & 0.000 & 0.000 & 0.000 & 0.000 & 0.000 & 0.038 \\
\hline \multirow[t]{2}{*}{ 2003-2007 } & -0.0038 & 0.0006 & $-0.0053^{c}$ & 0.0001 & & \\
\hline & 0.170 & 0.859 & 0.067 & 0.986 & & \\
\hline \multirow[t]{2}{*}{ 2005-2006 } & & & & & 0.0006 & 0.0083 \\
\hline & & & & & 0.913 & 0.181 \\
\hline \multirow[t]{2}{*}{ BID } & -0.0075 & $-0.0150^{\mathrm{b}}$ & -0.0022 & -0.0135 & 0.0035 & -0.0097 \\
\hline & 0.220 & 0.047 & 0.747 & 0.116 & 0.767 & 0.450 \\
\hline \multirow[t]{2}{*}{ TEND } & $0.0190^{\mathrm{a}}$ & $0.0163^{\mathrm{a}}$ & $0.0188^{\mathrm{a}}$ & $0.0140^{\mathrm{b}}$ & $0.0197^{\mathrm{a}}$ & $0.0249^{\mathrm{a}}$ \\
\hline & 0.000 & 0.001 & 0.000 & 0.014 & 0.006 & 0.009 \\
\hline \multirow[t]{2}{*}{ SERIAL } & $-0.0042^{\mathrm{c}}$ & $-0.0074^{\mathrm{b}}$ & -0.0018 & $-0.0058^{\mathrm{c}}$ & 0.0025 & 0.0014 \\
\hline & 0.086 & 0.020 & 0.490 & 0.100 & 0.596 & 0.806 \\
\hline \multirow[t]{2}{*}{ HOST } & 0.0141 & 0.0177 & 0.0111 & 0.0157 & -0.0091 & 0.0052 \\
\hline & 0.174 & 0.130 & 0.329 & 0.242 & 0.688 & 0.825 \\
\hline \multirow[t]{2}{*}{ INTER } & $0.0044^{\mathrm{c}}$ & 0.0039 & $0.0061^{\mathrm{b}}$ & 0.0054 & $0.0082^{c}$ & 0.0080 \\
\hline & 0.075 & 0.218 & 0.020 & 0.124 & 0.076 & 0.149 \\
\hline \multirow[t]{2}{*}{ FIN } & -0.0026 & -0.0018 & $-0.0063^{\mathrm{b}}$ & -0.0062 & $-0.0113^{\mathrm{b}}$ & $-0.0132^{\mathrm{b}}$ \\
\hline & 0.352 & 0.617 & 0.032 & 0.122 & 0.037 & 0.041 \\
\hline \multirow[t]{2}{*}{ TECH } & $-0.0134^{\mathrm{a}}$ & $-0.0144^{\mathrm{a}}$ & $-0.0150^{\mathrm{a}}$ & $-0.0170^{\mathrm{a}}$ & $-0.0152^{\mathrm{a}}$ & $-0.0139^{b}$ \\
\hline & 0.000 & 0.000 & 0.000 & 0.000 & 0.005 & 0.031 \\
\hline \multirow[t]{2}{*}{ RUNUP } & 0.0068 & 0.0180 & -0.0148 & 0.0021 & -0.0146 & 0.0317 \\
\hline & 0.591 & 0.268 & 0.399 & 0.932 & 0.626 & 0.414 \\
\hline \multirow[t]{2}{*}{ STOCK } & $-0.0152^{\mathrm{a}}$ & $-0.0164^{\mathrm{a}}$ & $-0.0138^{\mathrm{a}}$ & $-0.0140^{\mathrm{a}}$ & $-0.0099^{b}$ & -0.0075 \\
\hline & 0.000 & 0.000 & 0.000 & 0.000 & 0.043 & 0.200 \\
\hline \multirow[t]{2}{*}{ RSIZE } & $0.0062^{\mathrm{a}}$ & $0.0069^{\mathrm{a}}$ & $0.0068^{\mathrm{a}}$ & $0.0074^{\mathrm{a}}$ & $0.0056^{\mathrm{a}}$ & $0.0060^{\mathrm{a}}$ \\
\hline & 0.000 & 0.000 & 0.000 & 0.000 & 0.000 & 0.002 \\
\hline \multirow[t]{2}{*}{ PREM } & & $0.0155^{\mathrm{a}}$ & & $0.0191^{\mathrm{a}}$ & & 0.0142 \\
\hline & & 0.002 & & 0.001 & & 0.118 \\
\hline \multirow[t]{2}{*}{ RELQ } & & $-0.0040^{\mathrm{b}}$ & & -0.0026 & & -0.0031 \\
\hline & & 0.033 & & 0.258 & & 0.325 \\
\hline $\mathbf{N}$ & 2,509 & 1,456 & 2,067 & 1,146 & 767 & 482 \\
\hline Adj. $\mathbf{R}^{2}(\%)$ & 7.22 & 8.24 & 8.16 & 8.31 & 5.07 & 5.56 \\
\hline
\end{tabular}




\section{Table 8. Large Loss Deals}

The sample of acquisitions meets the criteria described in Table 1. Panel A reports the characteristics for acquiring firms that created large loss deals. Large loss deals are transactions that resulted in more than one billion dollar loss in the acquiring firms' market value during the $(-1,+1)$ announcementwindow. Panel B excludes large loss deals. ASIZE is the market capitalization (in $\$$ million) of the acquirer one month prior the acquisition announcement. Values are in 2007 dollars. ACARs are the acquirer's cumulative abnormal returns (CARs) over a 3-day announcement window. Market model parameters are estimated over the period $(-250,-15)$ relative to the announcement day. Difference tests are based on a t-test for means and a Wilcoxon-test for medians. a, b, and c denote significance at the $1 \%, 5 \%$, and $10 \%$ level, respectively.

\begin{tabular}{|c|c|c|c|c|c|c|c|c|c|}
\hline & & $\begin{array}{l}\text { All } \\
\text { (1) }\end{array}$ & $\begin{array}{c}\text { 1993-1999 } \\
\text { (2) }\end{array}$ & $\begin{array}{c}\text { 1998-1999 } \\
\text { (3) }\end{array}$ & $\begin{array}{c}2000-2002 \\
(4)\end{array}$ & $\begin{array}{c}2003-2007 \\
(5)\end{array}$ & $\begin{array}{c}2005-2006 \\
(6)\end{array}$ & (5)-(2) & $(6)-(3)$ \\
\hline \multicolumn{10}{|l|}{ Panel A: Large Loss Deals } \\
\hline No of Observations & & 153 & 68 & 46 & 49 & 36 & 19 & & \\
\hline$\%$ compared to Total Deals & & 4.77 & 3.57 & 6.77 & 8.46 & 4.99 & 6.48 & & \\
\hline \multirow[t]{2}{*}{ Dollar Gain/Loss } & sum & $-613,136$ & $-208,106$ & $-155,634$ & $-283,962$ & $-121,068$ & $-70,112$ & & \\
\hline & mean & $-4,007$ & $-3,060$ & $-3,383$ & $-5,795$ & $-3,363$ & $-3,690$ & 303 & 307 \\
\hline \multirow[t]{2}{*}{ ASIZE } & mean & 61,953 & 46,558 & 49,078 & 78,353 & 68,711 & 73,897 & $22,152^{\mathrm{c}}$ & 24,818 \\
\hline & median & 33,299 & 29,331 & 25,619 & 31,396 & 41,473 & 70,603 & 12,142 & $44,984^{\mathrm{b}}$ \\
\hline \multirow[t]{2}{*}{ ACARs } & mean & -8.59 & -8.87 & -9.62 & -10.23 & -5.82 & -5.56 & $3.04^{\mathrm{a}}$ & $4.06^{\mathrm{a}}$ \\
\hline & median & -7.03 & -8.16 & -8.96 & -8.52 & -4.97 & -4.94 & $3.19^{\mathrm{a}}$ & $4.02^{\mathrm{a}}$ \\
\hline \multicolumn{10}{|c|}{ Panel B: Non-Large Loss Deals } \\
\hline No of Observations & & 3,053 & 1,837 & 633 & 530 & 686 & 274 & & \\
\hline \% compared to Total Deals & & 95.23. & 96.43 & 93.23 & 91.54 & 95.01 & 93.52 & & \\
\hline \multirow[t]{2}{*}{ Dollar Gain/Loss } & sum & 58,182 & 40,554 & 39,706 & 11,298 & 6,329 & 7,060 & & \\
\hline & mean & 19.06 & 22.08 & 62.73 & 21.32 & 9.22 & 25.77 & 12.85 & -36.96 \\
\hline \multirow[t]{2}{*}{ ASIZE } & mean & 5,127 & 4,482 & 6,930 & 4,037 & 7,696 & 9,630 & $3,214^{\mathrm{a}}$ & $2,700^{\mathrm{c}}$ \\
\hline & median & 1,162 & 1,092 & 1,522 & 886 & 1,532 & 1,279 & $440^{\mathrm{a}}$ & $-243^{c}$ \\
\hline \multirow[t]{2}{*}{ ACARs } & mean & -1.14 & -0.89 & -1.16 & -1.63 & -1.45 & -1.46 & $-0.56^{\mathrm{b}}$ & -0.31 \\
\hline & median & -0.76 & -0.65 & -0.81 & -1.29 & -0.77 & -0.80 & $-0.12^{\mathrm{c}}$ & 0.02 \\
\hline
\end{tabular}




\section{Table 9. Acquirer Long-Run Returns}

The table reports monthly calendar time acquirer abnormal returns. The sample meets the criteria described in Table 1 . Acquirers enter the portfolio on the announcement month of each transaction and remain for 36 months. Abnormal returns are calculated using i) calendar time abnormal returns (CTARs) and ii) calendar time portfolio regressions (CTPRs). ACTARs acquirer abnormal returns are calculated as $C T A R_{i, t}=R_{i, t}-R_{\text {Size/BM benchmark,t. }}$ where $R_{i, t}$ is the return of acquirer $i$ at month $t$ and $R_{\text {Size/BM }}$ benchmark,t is the return of the corresponding 25 size and book-to-market reference portfolio for the same month as in Mitchell and Stafford (2000). The ACTAR is then given by the universal average of all mean monthly abnormal return observations. CTPR intercepts are from a time-series regression of the following form: $R_{p t}-R_{f t}=\alpha_{p}+b_{p}\left(R_{m t}-R_{f t}\right)+s_{p} S M B_{t}+h_{p} H M L_{t}+u_{p} U M D_{t}$ $+\varepsilon_{p t}$, where $R_{p t}-R_{f t}$, is the equally-weighted, monthly calendar time portfolio excess return and the independent variables are the Fama/French (1993) and Carhart (1997) factors. ACTAR difference tests are based on a t-test for means and a Wilcoxon-test for medians. p-values are reported in brackets below abnormal return estimates. a,b, and c denote statistical significance at the $1 \%, 5 \%$, and $10 \%$ level. Cal is the number of calendar months and $\mathrm{n}$ is the number of observations. Calendar months with less than 10 return observations are excluded from regressions.

\begin{tabular}{|c|c|c|c|c|c|c|c|c|c|}
\hline & & $\begin{array}{l}\text { All } \\
\text { (1) }\end{array}$ & $\begin{array}{c}1993-1999 \\
(2)\end{array}$ & $\begin{array}{c}\text { 1998-1999 } \\
(3)\end{array}$ & $\begin{array}{c}2000-2002 \\
(4)\end{array}$ & $\begin{array}{c}\text { 2003-2007 } \\
(5)\end{array}$ & $\begin{array}{c}2005-2006 \\
(6)\end{array}$ & (5)-(2) & $(6)-(3)$ \\
\hline \multirow[t]{15}{*}{ All } & ACTAR & $-0.252^{\mathrm{a}}$ & -0.126 & -0.208 & $-0.303^{c}$ & $-0.385^{b}$ & $-0.801^{\mathrm{a}}$ & -0.259 & -0.593 \\
\hline & $p$-value & [0.005] & {$[0.402]$} & [0.413] & [0.057] & [0.012] & {$[0.003]$} & {$[0.223]$} & [0.102] \\
\hline & $\mathrm{Cal}$ & 204 & 119 & 59 & 71 & 84 & 59 & & \\
\hline & CTPRa & -0.039 & 0.126 & 0.352 & 0.107 & $-0.257^{\mathrm{c}}$ & $-0.647^{\mathrm{a}}$ & & \\
\hline & $p$-value & [0.714] & [0.458] & [0.220] & [0.601] & [0.051] & [0.004] & & \\
\hline & $M k t-R f$ & $0.981^{\mathrm{a}}$ & $1.085^{\mathrm{a}}$ & $1.100^{\mathrm{a}}$ & $1.055^{\mathrm{a}}$ & $0.906^{\mathrm{a}}$ & $0.867^{\mathrm{a}}$ & & \\
\hline & $p$-value & {$[0.000]$} & [0.000] & [0.000] & [0.000] & {$[0.000]$} & {$[0.000]$} & & \\
\hline & $S M B$ & $0.405^{\mathrm{a}}$ & $0.420^{\mathrm{a}}$ & $0.411^{\mathrm{a}}$ & $0.545^{\mathrm{a}}$ & $0.649^{\mathrm{a}}$ & $0.611^{\mathrm{a}}$ & & \\
\hline & $p$-value & [0.000] & [0.000] & [0.000] & [0.000] & {$[0.000]$} & [0.000] & & \\
\hline & $H M L$ & $0.279^{\mathrm{a}}$ & $0.434^{\mathrm{a}}$ & $0.435^{\mathrm{a}}$ & $0.171^{\mathrm{a}}$ & $0.131^{\mathrm{b}}$ & $0.187^{\mathrm{b}}$ & & \\
\hline & $p$-value & [0.000] & [0.000] & [0.000] & [0.005] & [0.023] & [0.033] & & \\
\hline & $U M D$ & $-0.231^{\mathrm{a}}$ & $-0.289^{a}$ & $-0.294^{\mathrm{a}}$ & $-0.215^{\mathrm{a}}$ & $-0.215^{\mathrm{a}}$ & $-0.254^{\mathrm{a}}$ & & \\
\hline & $p$-value & [0.000] & [0.000] & [0.000] & {$[0.000]$} & [0.000] & [0.000] & & \\
\hline & $\mathrm{Cal}$ & 203 & 118 & 59 & 71 & 83 & 58 & & \\
\hline & $n$ & 3,170 & 1,885 & 665 & 571 & 714 & 290 & & \\
\hline \multirow[t]{15}{*}{ Cash } & ACTAR & -0.035 & -0.152 & -0.398 & 0.420 & -0.163 & -0.282 & -0.011 & 0.116 \\
\hline & $p$-value & [0.783] & [0.510] & [0.359] & [0.194] & [0.396] & [0.223] & [0.971] & [0.813] \\
\hline & Cal & 204 & 119 & 59 & 71 & 84 & 59 & & \\
\hline & CTPRa & $0.264^{c}$ & 0.266 & 0.228 & $0.902^{\mathrm{a}}$ & -0.041 & -0.264 & & \\
\hline & $p$-value & [0.065] & [0.210] & [0.552] & [0.008] & [0.792] & [0.270] & & \\
\hline & $M k t-R f$ & $0.899^{\mathrm{a}}$ & $0.971^{\mathrm{a}}$ & $0.969^{\mathrm{a}}$ & $0.738^{\mathrm{a}}$ & $0.936^{\mathrm{a}}$ & $0.900^{\mathrm{a}}$ & & \\
\hline & $p$-value & {$[0.000]$} & {$[0.000]$} & [0.000] & [0.000] & {$[0.000]$} & {$[0.000]$} & & \\
\hline & $S M B$ & $0.367^{\mathrm{a}}$ & $0.406^{\mathrm{a}}$ & $0.470^{\mathrm{a}}$ & $0.556^{\mathrm{a}}$ & $0.640^{\mathrm{a}}$ & $0.578^{\mathrm{a}}$ & & \\
\hline & $p$-value & [0.000] & [0.000] & [0.000] & [0.000] & [0.000] & [0.000] & & \\
\hline & $H M L$ & $0.353^{\mathrm{a}}$ & $0.560^{\mathrm{a}}$ & $0.646^{\mathrm{a}}$ & $0.321^{\mathrm{a}}$ & -0.084 & -0.052 & & \\
\hline & $p$-value & [0.000] & {$[0.000]$} & {$[0.000]$} & {$[0.001]$} & [0.212] & [0.589] & & \\
\hline & $U M D$ & $-0.171^{\mathrm{a}}$ & $-0.178^{\mathrm{a}}$ & $-0.207^{\mathrm{a}}$ & $-0.213^{\mathrm{a}}$ & $-0.161^{a}$ & $-0.166^{\mathrm{a}}$ & & \\
\hline & $p$-value & {$[0.000]$} & {$[0.000]$} & {$[0.000]$} & [0.000] & [0.000] & [0.001] & & \\
\hline & Cal & 195 & 113 & 55 & 67 & 81 & 54 & & \\
\hline & $n$ & 672 & 317 & 99 & 117 & 238 & 99 & & \\
\hline
\end{tabular}




\begin{tabular}{|c|c|c|c|c|c|c|c|c|c|}
\hline \multirow[t]{15}{*}{ Stock } & ACTAR & $-0.391^{b}$ & 0.107 & 0.031 & $-0.677^{b}$ & $-0.781^{b}$ & $-1.102^{b}$ & $-0.888^{b}$ & $-1.133^{\mathrm{c}}$ \\
\hline & $p$-value & [0.012] & [0.619] & [0.937] & [0.041] & [0.013] & {$[0.021]$} & [0.019] & [0.064] \\
\hline & Cal & 204 & 119 & 59 & 71 & 84 & 59 & & \\
\hline & CTPRa & -0.210 & 0.342 & 0.606 & -0.158 & $-0.651^{\mathrm{b}}$ & $-1.204^{b}$ & & \\
\hline & $p$-value & [0.209] & [0.125] & [0.151] & [0.618] & [0.032] & [0.012] & & \\
\hline & $M k t-R f$ & $0.992^{\mathrm{a}}$ & $1.119^{\mathrm{a}}$ & $1.130^{\mathrm{a}}$ & $1.213^{\mathrm{a}}$ & $0.859^{\mathrm{a}}$ & $0.810^{\mathrm{a}}$ & & \\
\hline & $p$-value & {$[0.000]$} & [0.000] & [0.000] & [0.000] & [0.000] & [0.000] & & \\
\hline & $S M B$ & $0.402^{\mathrm{a}}$ & $0.432^{\mathrm{a}}$ & $0.425^{\mathrm{a}}$ & $0.700^{\mathrm{a}}$ & $0.687^{\mathrm{a}}$ & $0.458^{\mathrm{b}}$ & & \\
\hline & $p$-value & [0.000] & [0.000] & [0.000] & [0.000] & [0.000] & {$[0.046]$} & & \\
\hline & $H M L$ & $0.140^{\mathrm{a}}$ & $0.348^{\mathrm{a}}$ & $0.298^{\mathrm{b}}$ & -0.148 & 0.180 & 0.285 & & \\
\hline & $p$-value & [0.009] & [0.000] & [0.013] & [0.108] & [0.164] & [0.133] & & \\
\hline & $U M D$ & $-0.228^{\mathrm{a}}$ & $-0.334^{\mathrm{a}}$ & $-0.334^{\mathrm{a}}$ & $-0.258^{a}$ & $-0.132^{\mathrm{b}}$ & -0.109 & & \\
\hline & $p$-value & [0.000] & [0.000] & [0.000] & [0.000] & [0.031] & {$[0.217]$} & & \\
\hline & $\mathrm{Cal}$ & 202 & 117 & 59 & 68 & 81 & 54 & & \\
\hline & $n$ & 1,525 & 1,102 & 376 & 248 & 175 & 67 & & \\
\hline \multirow[t]{15}{*}{ Hybrid } & ACTAR & $-0.441^{\mathrm{a}}$ & $-0.651^{\mathrm{a}}$ & $-0.824^{\mathrm{a}}$ & -0.209 & $-0.397^{\mathrm{c}}$ & $-0.993^{b}$ & 0.254 & -0.169 \\
\hline & $p$-value & {$[0.001]$} & {$[0.001]$} & [0.009] & [0.510] & [0.057] & [0.013] & [0.372] & [0.732] \\
\hline & $\mathrm{Cal}$ & 204 & 119 & 59 & 71 & 84 & 59 & & \\
\hline & CTPRa & -0.160 & -0.315 & -0.252 & 0.190 & $-0.322^{c}$ & $-0.479^{c}$ & & \\
\hline & $p$-value & [0.187] & [0.110] & [0.457] & [0.381] & [0.056] & [0.087] & & \\
\hline & $M k t-R f$ & $0.973^{\mathrm{a}}$ & $1.096^{\mathrm{a}}$ & $1.134^{\mathrm{a}}$ & $1.024^{\mathrm{a}}$ & $0.888^{\mathrm{a}}$ & $0.867^{\mathrm{a}}$ & & \\
\hline & $p$-value & [0.000] & [0.000] & [0.000] & [0.000] & [0.000] & [0.000] & & \\
\hline & $S M B$ & $0.417^{\mathrm{a}}$ & $0.392^{\mathrm{a}}$ & $0.348^{\mathrm{a}}$ & $0.365^{\mathrm{a}}$ & $0.601^{\mathrm{a}}$ & $0.614^{\mathrm{a}}$ & & \\
\hline & $p$-value & [0.000] & [0.000] & [0.000] & [0.000] & [0.000] & [0.000] & & \\
\hline & $H M L$ & $0.489^{\mathrm{a}}$ & $0.566^{\mathrm{a}}$ & $0.596^{\mathrm{a}}$ & $0.635^{\mathrm{a}}$ & $0.341^{\mathrm{a}}$ & $0.312^{\mathrm{a}}$ & & \\
\hline & $p$-value & [0.000] & [0.000] & [0.000] & [0.000] & [0.000] & [0.007] & & \\
\hline & $U M D$ & $-0.231^{\mathrm{a}}$ & $-0.244^{\mathrm{a}}$ & $-0.250^{\mathrm{a}}$ & $-0.173^{\mathrm{a}}$ & $-0.291^{\mathrm{a}}$ & $-0.431^{\mathrm{a}}$ & & \\
\hline & $p$-value & [0.000] & [0.000] & [0.000] & [0.000] & [0.000] & [0.000] & & \\
\hline & $\mathrm{Cal}$ & 199 & 112 & 57 & 68 & 81 & 56 & & \\
\hline & $n$ & 973 & 471 & 197 & 201 & 301 & 124 & & \\
\hline
\end{tabular}




\section{Figure 1. Acquisition Activity Through Time}

The figure shows the total value (in \$ billions) spent between 1993 and 2007 in U.S., completed, domestic acquisitions as reported in Thomson Financial SDC. Values are expressed in 2007 dollars. "All deals" include all reported corporate control transactions. Transactions labeled as spinoffs, recapitalizations, self-tenders, exchange offers, repurchases, and privatizations are excluded.

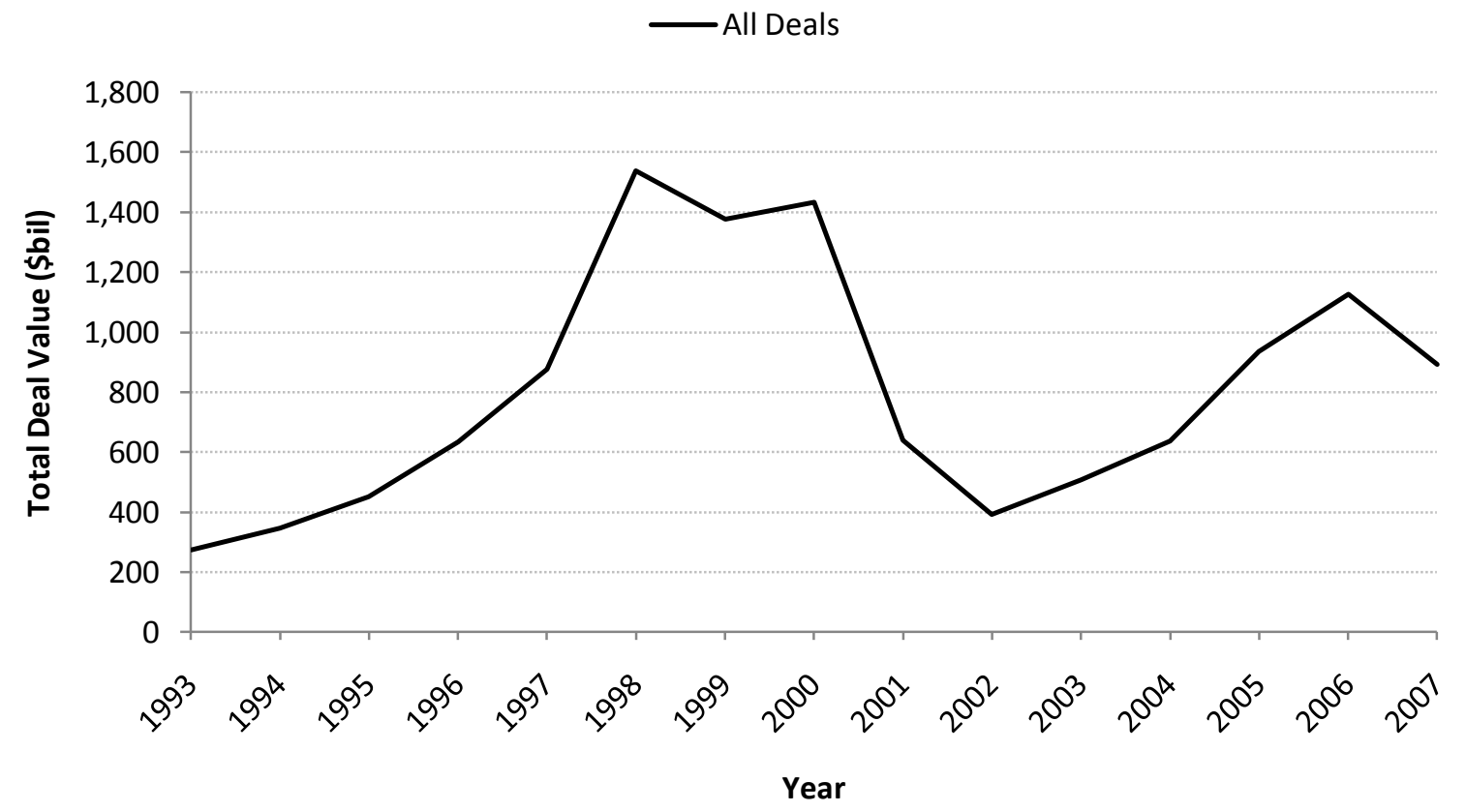




\section{Figure 2. Acquisition Premiums Through Time}

Average premium paid in domestic, public acquisitions between 1993 and 2007. The sample of acquisitions meets the criteria described in Table 1. Premium is the offer price over the target's share price 4 weeks prior the acquisition announcement multiplied by 100 and is reported for observations between zero and 200. Target Return $(-63,126)$ is the market adjusted target return for a period $(-63,126)$ around the announcement day.

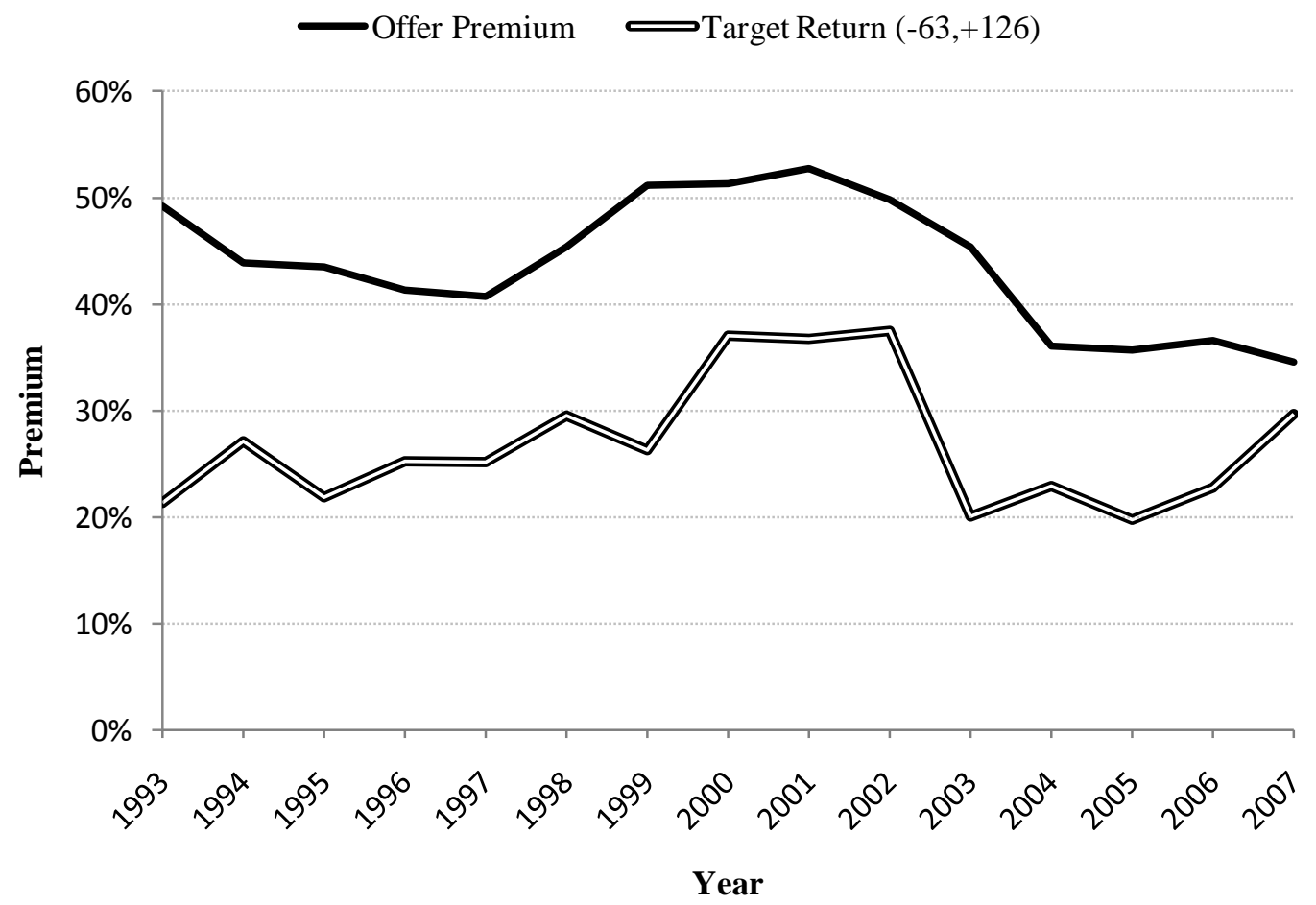

